Article

\title{
Biocatalysis of Industrial Kraft Pulps: Similarities and Differences between Hardwood and Softwood Pulps in Hydrolysis by Enzyme Complex of Penicillium verruculosum
}

\author{
Andrey S. Aksenov ${ }^{1, *}$, Irina V. Tyshkunova ${ }^{2}$, Daria N. Poshina ${ }^{2}$, Anastasia A. Guryanova ${ }^{1}$, \\ Dmitry G. Chukhchin ${ }^{1}$, Igor G. Sinelnikov ${ }^{3}$, Konstantin Y. Terentyev ${ }^{1,4}$, Yury A. Skorik ${ }^{2}$ (D), \\ Evgeniy V. Novozhilov ${ }^{1}$ and Arkady P. Synitsyn ${ }^{3,5}$ \\ 1 Northern (Arctic) Federal University, Northern Dvina Embankment 17, 163000 Arkhangelsk, Russia; \\ stasya658@yandex.ru (A.A.G.); dimatsch@mail.ru (D.G.C.); k.terentev@narfu.ru (K.Y.T.); \\ noev50@gmail.com (E.V.N.) \\ 2 Institute of Macromolecular Compounds of the Russian Academy of Sciences, Bolshoy prospect V.O. 31, \\ 199004 St. Petersburg, Russia; tisha19901991@yandex.ru (I.V.T.); poschin@yandex.ru (D.N.P.); \\ yury_skorik@mail.ru (Y.A.S.) \\ 3 Federal State Institution, Federal Research Centre (Fundamentals of Biotechnology) of the Russian Academy \\ of Sciences, Leninsky prospect, 33, build. 2, 119071 Moscow, Russia; sinelnikov.i@list.ru (I.G.S.); \\ apsinitsyn@gmail.com (A.P.S.) \\ 4 Federal Center for Integrated Arctic Research, Russian Academy of Sciences, Northern Dvina Embankment 23, \\ 163000 Arkhangelsk, Russia \\ 5 Chemical Department, Moscow State University, Vorobyevy Gory, 1-11, 119992 Moscow, Russia \\ * Correspondence: a.s.aksenov@narfu.ru; Tel.: +7-921-2915446
}

Received: 28 April 2020; Accepted: 11 May 2020; Published: 13 May 2020

check for updates

\begin{abstract}
Kraft pulp enzymatic hydrolysis is a promising method of woody biomass bioconversion. The influence of composition and structure of kraft fibers on their hydrolysis efficiency was evaluated while using four substrates, unbleached hardwood pulp (UHP), unbleached softwood pulp (USP), bleached hardwood pulp (BHP), and bleached softwood pulp (BSP). Hydrolysis was carried out with Penicillium verruculosum enzyme complex at a dosage of 10 filter paper units (FPU)/g pulp. The changes in fiber morphology and structure were visualized while using optical and electron microscopy. Fiber cutting and swelling and quick xylan destruction were the main processes at the beginning of hydrolysis. The negative effect of lignin content was more pronounced for USP. Drying decreased the sugar yield of dissolved hydrolysis products for all kraft pulps. Fiber morphology, different xylan and mannan content, and hemicelluloses localization in kraft fibers deeply affected the hydrolyzability of bleached pulps. The introduction of additional xylobiase, mannanase, and cellobiohydrolase activities to enzyme mixture will further improve the hydrolysis of bleached pulps. A high efficiency of never-dried bleached pulp bioconversion was shown. At 10\% substrate concentration, hydrolysates with more than $50 \mathrm{~g} / \mathrm{L}$ sugar concentration were obtained. The bioconversion of never-dried BHP and BSP could be integrated into working kraft pulp mills.
\end{abstract}

Keywords: kraft pulp; cellulose; xylan; enzymatic hydrolysis; Penicillium verruculosum; glucose; xylose

\section{Introduction}

Lignocelluloses have been the focus of much attention as promising feedstock for the sustainable production of non-food-derived sugars, from the viewpoint of both energy and the environment. Numerous physical, chemical, and biological methods for converting lignocellulose to sugars are under 
development, but those that rely on enzymes are particularly attractive. Enzymes can potentially serve as industrial catalysts for biomass conversion, providing benefits, such as high specificity, low energy, and reagent consumption, and little environmental pollution [1].

Consequently, the conversion of lignocellulosic biomass into simple carbohydrates, phenolics, aromatics, and other substances remains a major challenge. The resulting conversion of cellulose to glucose can produce a number of useful products, including biofuels, as well as different organic acids. Lignocellulose is a very challenging material for enzymatic attack, due to its complex and compact structure composed of many biopolymers, each with a different chemical composition and physical structure [2].

Bioconversion processes are preferentially carried out through the enzymatic saccharification of pretreated lignocellulosic substrates. The direct conversion of untreated lignocellulose with enzymes has not yet been technologically rendered, mainly due to the well-known recalcitrance of biomass to enzymatic hydrolysis. Pretreatment plays a crucial role in biomass conversion, as it aids in overcoming the chemical and structural difficulties that are associated with lignocelluloses and allows for the cost-effective production of fermentable sugars via enzymatic saccharification [3-5].

The main barrier to enzymatic saccharification of lignocelluloses is lignin. Carbohydrases readily digest the hemicellulose components, whereas lignin can induce nonproductive binding of cellulases by various mechanisms, as well as a reduction of cellulase catalytic activity due to the possible inhibition of small phenolic molecules, thereby considerably hindering the hydrolytic efficiency [6,7]. Strategies to minimize these cellulase-lignin interactions, such as enzyme engineering [6], substrate modification, and additive blocking, have therefore undergone intensive development [7].

One of the most promising pretreatments of wood biomass is alkali-based technology, such as kraft pulping, as this provides highly efficient delignification. Important advantages of kraft pulping as a pretreatment stage of raw wood materials are as follows [8]: first, the inorganic chemicals used for pulping are regenerated; second, dissolved organic matter and residual lignin are burned to produce energy; and third, a well-established wastewater treatment system is used. This is a highly attractive prospect, as it would utilize the equipment and chemical recovery systems that are already well developed in the pulp industry, thereby lowering the capital cost of pretreatment and providing additional benefits for pulp mills [9].

As cellulose is an unbranched crystalline polymer, several cellulases are needed to degrade it efficiently. Cellulases hydrolyze $\beta-1,4-\mathrm{D}$-glucan bonds, releasing cello-oligosaccharides, cellobiose, or glucose. The complete degradation of cellulose is carried out by an enzymatic complex, which includes endo- $\beta$-1,4-glucanases (EC 3.2.1.4), cellobiohydrolases (EC 3.2.1.91 and EC 3.2.1.176), and $\beta$-glucosidases (EC 3.2.1.21) [10].

The production of cellulase cocktails has been widely explored; however, there are still some main challenges with enzymes that need to be overcome in order to develop the sustainable production of bioethanol [10]. Trichoderma fungi (T. reesei, T. viride, T, longibrachiatum) have high secretory ability of enzymes with different substrate specificity [11]. Various companies manufacture enzyme preparations that are produced by these fungi. Commercial preparations of Trichoderma fungus strains, like Cellic HTec series (Novozymes, Denmark), have necessary activities for enzymatic hydrolysis of cellulose-containing substrates [12,13]. When comparing to Trichoderma, the Penicillium verruculosum enzyme complex, along with highly active enzymes (endoglucanase, cellobiohydrolase, xylanase), additionally contains significant $\beta$-glucosidase activity [14].

Penicillium cellulases are superior in their rate of hydrolysis and the glucose yield from various cellulose-containing substrates at the same dosage for protein concentration [10]. The advantages of Penicillium verruculosum over Trichoderma reesei enzymes are a higher secretory ability (40-50 g/L of extracellular protein), reduced affinity for lignin, and low sensitivity to inhibition by lignin derivatives $[6,13,14]$. For examples, cellulases from Penicillium verruculosum have shown good performance on different substrates [15-17] and they can successfully compete with the Trichoderma enzymes, which are known for their high cellulolytic activity. 
The composition of enzyme complexes includes xylanases that are intended for the destruction of xylan to improve the effect of cellulases. The xylanase activity is quite high in the Penicillium verruculosum enzyme complex $[12,17]$. This ensures the bioconversion of xylan as a biopolymer. Biocatalysis leads to the accumulation of soluble xylan degradation products in hydrolysates in the form of xylose, xylobiose, and xylooligomers [18].

Kraft pulp is technical pulp obtained by kraft pulping of raw wood materials. Kraft mills produce four types of kraft pulp: unbleached hardwood pulp (UHP), unbleached softwood pulp (USP), bleached hardwood pulp (BHP), and bleached softwood pulp (BSP). Woody kraft pulp has been widely studied as a substrate for bioconversion $[15,17,19-27]$. Some studies have been performed with samples that were obtained after laboratory kraft pulping [23-26]. In the industrial kraft pulping, which is usually carried out as a continuous process, the same residual lignin content in pulp characterized by the kappa number can be obtained by rapid cooking with high chemical consumption and high temperature, or by slow cooking with low chemical consumption and low temperature. The topochemical effect leads to the formation of kraft pulp fiber, the outer part of which has a higher concentration of residual lignin when compared to the average value in the pulp [8]. As a result, lignin in kraft pulp fiber is mostly located in the outer layer of the fiber [28]. From $85 \%$ to $90 \%$ of the residual lignin in unbleached kraft pulp was isolated as lignin-carbohydrate complexes (LCCs) of three types: xylan-lignin, glucomannan-lignin-xylan, and glucan-lignin [29]. The most stable LCC formed during kraft pulping of pine pulp contained mannan and xylan, which are most recalcitrant and they remain in the pulp with a decreasing kappa number [29]. Kraft pulp fibers are also characterized by an increased concentration of xylan in the outer layers of the cell wall [8]. Non-cellulose components on the surface of these fibers present a physical barrier to cellulases. In addition, the fibers partially retain the primary walls, since the delignification in the kraft process mainly starts from the cell lumen. The cellulose microfibrils of primary walls show high resistance to the action of cellulases [30]. The structure of the surface layers distinguishes kraft pulp fibers from other lignocellulose fibers proposed for the bioconversion of cellulose into glucose.

Kraft pulp remains poorly understood as a substrate for bioconversion, despite conducted research. The influence of the composition and localization of hemicelluloses of hardwood and softwood pulps on enzymatic hydrolysis has not been sufficiently studied. Residual lignin has a negative effect on biocatalysis. For example, a decrease in the lignin content from $18.6 \%$ to $4.8 \%$ led to a more than double increase in the reducing sugars (RS) yield, from 31.6\% to 67.5\% [21]. Never-dried USP bioconversion was performed at a substrate concentration of $5 \%$ with an enzyme mixture that was prepared with Novozymes Cellic ${ }^{\circledR}$ CTec2 cellulase enzyme and Cellic ${ }^{\circledR}$ HTec2 hemicellulase enzyme at a dosage of $10 \mathrm{FPU} / \mathrm{g}$.

The role of (LCCs with xylan and mannan present in kraft pulp is not well understood $[18,29,31]$. Researchers used a large dosage of enzyme preparations and reduced the concentration of the substrate to neutralize the influence of lignin. Conventional enzymatic hydrolysis of kraft pulp is typically carried out at a low substrate concentration, as a rule no more than $3 \%[19,23,24,26]$.

The research direction of increasing the efficiency of bioconversion due to increasing the dosage of enzyme preparations and reducing the substrate concentration allows for the assessment of the potential impact of catalytic action on kraft pulp. However, such a technique conflicts with the requirements for industrial implementation of enzymatic hydrolysis. A substrate consistency below $5 \%$ solid content leads to a sugar concentration below $5 \%$ in the hydrolysate, thus a final concentration of ethanol less than $2 \%(\mathrm{w} / \mathrm{w})$ after fermentation [20].

A significant portion of industrial kraft pulp is produced in bleached form. If up to $90-97 \%$ of wood lignin is dissolved in kraft pulping, the lignin is almost completely removed in the process of industrial pulp bleaching. It is obvious that the bioconversion of bleached kraft pulps is faster and more complete under milder conditions in the absence of lignin $[17,19]$. It was shown that fiber fractions obtained from eucalyptus BHP at a substrate concentration of $2 \%$ and an enzyme dosage of 
$10 \mathrm{FPU} / \mathrm{g}$ after $48 \mathrm{~h}$ of bioconversion yielded $92.8-93.2 \%$ glucose [19]. The role of xylan and mannan is increased in the absence of lignin in bleached pulp.

Industrial dry bleached kraft pulp and various types of paper can be used as substrates for bioconversion into glucose. The drying of cellulose fibers has a significant effect on their structure and properties [32]. Several papers describe changes in cellulose fiber structures related to hornification [15,22,32-36]. Cellulose microfibrils can form additional hydrogen bonds in amorphous areas when water is removed during drying. The formation of irreversible or partially reversible $\mathrm{H}$-bonds is called hornification [33]. A high content of hemicellulose has been shown to reduce the negative effect of hornification by preventing the aggregation of microfibrils in cellulose fibers [34,35].

Drying and the associated hornification decrease the reactivity of kraft pulp due to decreased swelling and cellulase accessibility $[15,22]$. From this point of view, the enzymatic hydrolysis of never-dried industrial kraft pulp is of particular interest. In our previous study [17], we compared the effectiveness of biocatalysis of industrial hardwood and softwood pulps of cellulases from Penicillium verruculosum. The effect of the dosage of the Penicillium verruculosum enzyme complex was verified. It was established that a high conversion of never-dried pulp was achieved using a relatively low dosage of $10 \mathrm{FPU} / \mathrm{g}$ of pulp. It was shown that the crystallinity degree of BHP and BSP in enzymatic hydrolysis changed through a maximum due to the predominant degradation of the amorphous component at the beginning of the bioconversion process. Further study of the biocatalysis features of hardwood and softwood kraft pulps will provide recommendations for optimizing the composition of enzyme preparations by a set of activities and their ratio. The composition of non-hydrolysable residues and their structure, properties, and possibilities for rational use are not sufficiently studied.

The present study examined the biocatalysis of four substrates (UHP, USP, BHP, and BSP) by the Penicillium verruculosum enzyme complex. The aim was to evaluate the impact of the hardwood and softwood kraft pulp composition and structural fiber features on hydrolysis efficiency and to provide recommendations for improving the bioconversion of kraft pulps into hexoses and pentoses.

\section{Results and Discussion}

\subsection{Influence of Lignin on Bioconversion of Never-Dried Kraft Pulp}

Most of the studies of kraft pulp bioconversion to glucose have been conducted with unbleached kraft pulps that contain kraft lignin [21,24]. There is a general opinion that the lower the lignin proportion, the higher the bioconversion degree of cellulose into glucose.

In our study, never-dried UHP and USP were taken to assess the effect of kraft lignin on biocatalysis. A $5 \%$ substrate concentration was assumed. Other biocatalysis conditions were $24 \mathrm{~h}$ duration and dosage of Penicillium verruculosum enzyme complex at $10 \mathrm{FPU} / \mathrm{g}$. The lignin content was $2.1 \%$ and $3.0 \%$ for UHP and USP, respectively. There is a general pattern for unbleached pulps: kraft lignin has a negative effect on the results of bioconversion, even at a low content (Figure 1).

The best results under the selected bioconversion conditions were obtained while using never-dried UHP among the unbleached pulps (Figure 1). The yield of glucose and RS for never-dried UHP sample was $41.9 \%$ and $55.3 \%$, respectively. It should be noted that the content of residual lignin in UHP was 1.5 times lower than in USP. The glucose yield in enzymatic hydrolysis of never-dried USP with a higher lignin content was $13 \%$ lower and the RS yield was $8 \%$ lower when compared to UHP (Figure 1). 


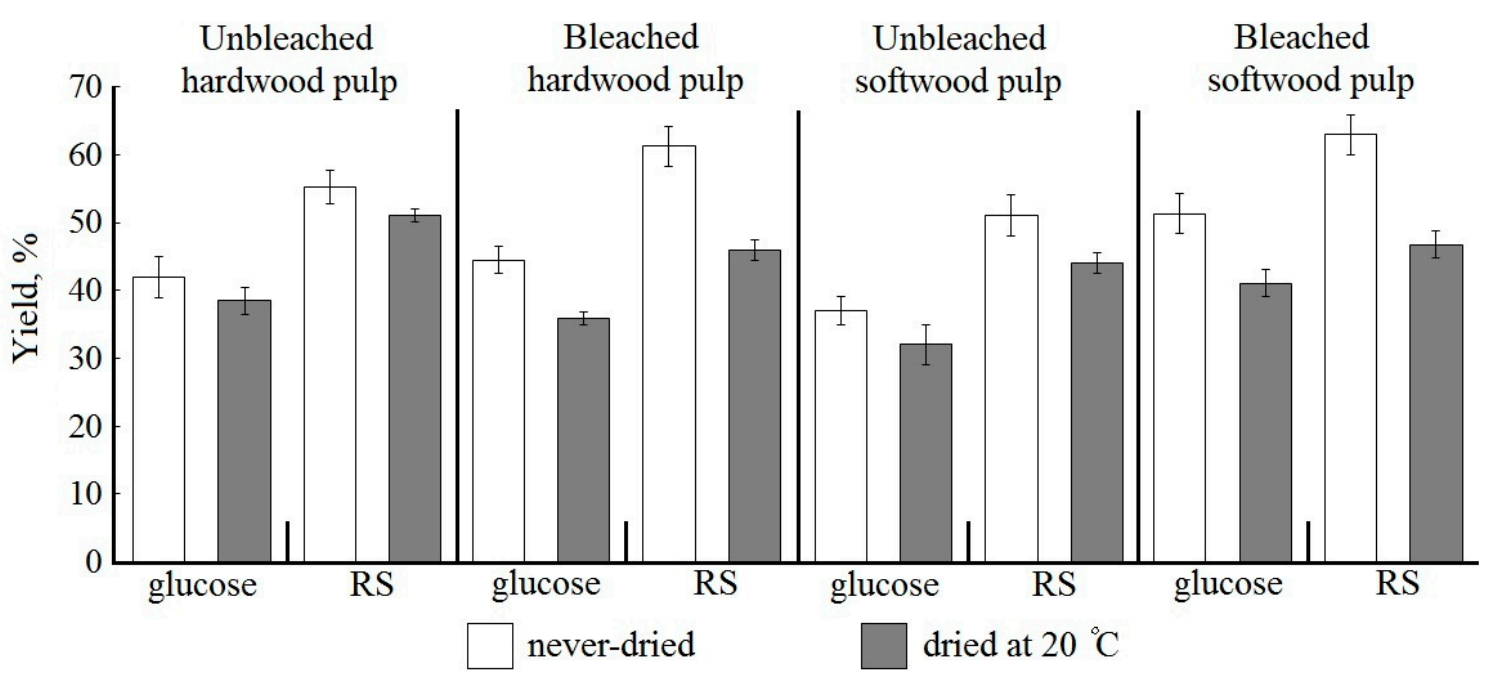

Figure 1. Effect of lignin and drying on bioconversion of kraft pulp.

Even a very small amount of kraft lignin (2-3\%) negatively affects the results of enzymatic hydrolysis (Figure 1). The possible reasons for the limited hydrolysis of unbleached kraft pulp include unproductive absorption and inhibition of cellulase action by soluble lignin degradation products. Non-specified sorption of cellulases onto the kraft lignin due to its low content in pulp probably has limited value and it can be compensated by increased dosage of enzyme complex. In UHP hydrolysate, the lignin concentration was $45 \mathrm{mg} / \mathrm{L}$ and $53 \mathrm{mg} / \mathrm{L}$ at $24 \mathrm{~h}$ and $48 \mathrm{~h}$ of enzymatic hydrolysis, respectively. In USP hydrolysate, lignin concentration was lower, $21 \mathrm{mg} / \mathrm{L}$ and $37 \mathrm{mg} / \mathrm{L}$ (Table 1). Probably dissolved lignin does not inhibit the biocatalysis process at such low concentrations. Under the action of the Penicillium verruculosum enzyme complex, only $4.3-5.0 \%$ UHP lignin and 1.4-2.5\% USP lignin passed into the solution. It was obvious that almost all of the kraft lignin remained in the mass during enzymatic hydrolysis. Dissolved lignin represents $4-5 \%$ of hardwood pulp lignin and $1-3 \%$ of softwood pulp lignin, while most of the lignin was undissolved and remained in non-hydrolyzed residue.

Table 1. Lignin and mannose concentration in hydrolysates of unbleached pulps.

\begin{tabular}{cccc}
\hline \multirow{2}{*}{ Pulp } & \multicolumn{2}{c}{ Lignin Concentration, $\mathbf{~ g / L}$} & Mannose Concentration, $\mathbf{m g} / \mathbf{L}$ \\
\cline { 2 - 4 } & $\mathbf{2 4} \mathbf{h}$ & $\mathbf{4 8} \mathbf{~}$ & $\mathbf{2 4} \mathbf{~}$ \\
\hline Hardwood & $45 \pm 1$ & $53 \pm 1$ & $78 \pm 2$ \\
Softwood & $21 \pm 1$ & $37 \pm 2$ & $72 \pm 1$ \\
\hline
\end{tabular}

During the kraft cooking to a high kappa number, most of the residual lignin remains bounded to xylan, however when cooking proceeds to a low kappa number, glucomannan-lignin complexes prevail. Lignin-carbohydrate complexes with glucomannan are located mainly on the surface of cellulose microfibrils [37]. Mannan is partially covered by adsorbed xylan inside the cell wall of kraft pulp fibers. This localization reduces the availability of mannan for enzymes [18].

Mannose occurred in hydrolysates, but in significantly smaller amounts than xylan destruction products. After $24 \mathrm{~h}$ of UHP enzymatic hydrolysis, the mannose concentration was $78 \mathrm{mg} / \mathrm{L}$ (Table 1), and glucomannan conversion into mannose was $47 \%$ in hydrolysate. In USP hydrolysate, the concentration was $72 \mathrm{mg} / \mathrm{L}$; therefore, glucomannan conversion into mannose was only $2 \%$. Thus, the main amount of glucomannan remained in USP as part of the LCC. For hardwood pulps with a mannan content of $0.3 \%$, this is less important when compared to softwood pulps with a mannan content of $6.8 \%$. Mannose and mannooligosaccharides were shown to inhibit cellulases and decrease the conversion of substrates [38,39]. However, they exert strong inhibition at higher concentrations $(2.5 \mathrm{~g} / \mathrm{L}$ and higher) than the mannose concentrations that were found in UHP and USP hydrolysates. 
It should be noted that the main reason for the limited hydrolysis of unbleached kraft pulp is that the residual lignin in the composition of LCC with mannan and xylan reduces the availability of cellulose for cellulase action. The cellulose content is higher in USP than in UHP. However, the percentage of glucose in hydrolysate after UHP bioconversion is $76.0 \pm 1.2 \%$ when compared to $73.0 \pm 1.4 \%$ in USP hydrolysate. Xylanase, part of the Penicillium verruculosum enzyme complex, largely destroys the xylan component of LCC, thereby increasing the availability of cellulose for cellulases. This applies equally to UHP and USP. It was shown that the degree of crystallinity of softwood and hardwood kraft pulps increased in the first stage of the process (3-6 h) due to the enhanced destruction of xylan and amorphous cellulose by xylanase and endogluconase, respectively [17]. In our opinion, LCC with glucomannan has a strong negative effect on the enzymatic hydrolysis of cellulose in USP. The glucomannan of the LCC is resistant to the action of Penicillium verruculosum enzyme complex, since the biocatalytic mannanase activity in this complex is at a low level. It can be recommended to include mannanase in the enzyme complex to optimize USP bioconversion. For UHP bioconversion, where the glucomannan content is low, it is sufficient to have only xylanase for successful enzymatic hydrolysis.

When bleaching kraft pulp, the main tasks are to remove the lignin and improve the pulp brightness. Carbohydrates, mainly xylan located on the fiber surface, are dissolved in approximately equal measure when LCC is destroyed and lignin is dissolved.

For never-dried hardwood pulp, lignin removal, and LCC destruction during bleaching stimulated slightly improved biocatalysis: glucose yield from BHP increased by $6.2 \%$ and RS yield by $11 \%$ when compared to UHP.

It can be concluded that the destruction of cellulose and xylan during the conversion of never-dried unbleached and bleached hardwood kraft pulp occurs in approximately equal proportions.

Residual lignin removal and LCC destruction with xylan and mannan in the bleaching leads to a significant increase in the yield of target products during enzymatic hydrolysis of never-dried softwood kraft pulp. Of particular importance is LCC destruction with glucomannan, which is localized near cellulose microfibrils. The yield of glucose from BSP was $51.3 \%$ of oven-dry pulp and the RS yield was $62.9 \%$. Glucose yield increased by $38 \%$ and RS by $23 \%$ when compared to USP (Figure 1 ). The ratio of glucose and non-glucose sugars in softwood pulp hydrolysate significantly improved; the glucose content was $82 \%$. Never-dried BSP bioconversion gave the best results for all the main targets.

\subsection{Effect of Drying on Bioconversion of Unbleached and Bleached Kraft Pulps}

Drying and related hornification decrease the reactivity of kraft pulp due to decreased swelling and cellulase accessibility $[15,22]$. The hornification degree increases with the increasing drying temperature of bleached kraft pulp [40]. In our research, drying, even under mild conditions, significantly reduced the reactivity of unbleached and bleached kraft pulp during enzymatic hydrolysis (Figure 1). The least negative drying effect was shown for UHP, with the yield of glucose and RS decreasing by $8-9 \%$. The decrease in the yield of soluble bioconversion products for USP was $13-14 \%$. It is demonstrated that the lignin content has no significant effect on the hydrolyzability of dried pulps [22]. This can be explained by the fact that lignin in unbleached pulp might play a positive role as an amorphous material, preventing the aggregation of cellulose microfibrils during fiber hornification and reducing hornification caused by drying. Obviously, hemicelluloses in kraft cellulose also have a positive effect on reducing the hornification degree. Thus, the negative effects of drying of unbleached kraft pulps on enzymatic hydrolysis turned out to be relatively small. The most important factor determining the hornification of dry pulps was the supramolecular structure [22,41]. Cellulose conversion to glucose mainly depended on the specific surface area and average pore size. In this study [22], the pore volume of the substrate was determined from fiber saturation point measurements. It is considered that the pore sizes of the fiber wall should be greater than typical dimensions of enzyme molecules, around $10 \mathrm{~nm}$ [42]. For dry birch BHP, the average pore size was $19 \mathrm{~nm}$ [22]. 
It should be noted that previously high-glucose yields were obtained from dried UHP and USP [22-25]. In one study [25], it was even concluded that the complete removal of lignin was not necessary in order to obtain a sufficiently high yield of glucose and RS from birch and beech pulps. However, these results were obtained when enzymatic hydrolysis was performed at a low substrate concentration and high enzyme dosage, approximately $67 \mathrm{FPU} / \mathrm{g}$.

It was demonstrated that there was some optimal lignin content in the bioconversion of pine USP [25], since the glucose yield was $11.3 \%$ higher at a kappa number up to 47.7 than at a lower or higher kappa number (17.2 and 86.2, respectively). Obviously, this does not agree with the concept that the higher the lignin content, the lower the efficiency of enzymatic hydrolysis. However, in our opinion, the deterioration of enzymatic hydrolysis results at a very low kappa number (17.2) is due to the fact that the lignin content in this case was insufficient for preventing strong compaction of cellulose microfibrils during drying.

Reactivity during drying decreases significantly more for bleached than unbleached kraft pulp (Figure 1). The negative effect of drying in BHP and BSP is shown to be equal, despite the different content of cellulose and hemicellulose. Glucose yield is reduced by $19-20 \%$ and RS yield by $25-26 \%$. Such significant decreases in the yield of soluble products of enzymatic hydrolysis occurred when only $2-3 \%$ of lignin was removed. Ultrastructural changes that are caused by the destruction of tightly packed regions of the cell wall resulting from delignification play an important role [43]. The ability of cellulose to form highly ordered supramolecular structures supported by many new intermolecular hydrogen bonds is enhanced as a result of lignin removal [22].

Thus, pulp drying leads to the hornification of the fiber and the formation of a dense structure of the cell wall, which reduces the availability of the substrate to enzymes. A comparison of the results for hydrolysis of bleached and unbleached pulp suggests a strong effect of bleaching on improving the hydrolyzability of kraft pulp. Since the best results were obtained while using never-dried bleached kraft pulps, only these pulps were used in further experiments.

\subsection{Changes of Kraft Pulp Fibers Length and Width During Enzymatic Hydrolysis}

Significant changes in the length and width of kraft pulp fibers occurred at early stages of enzymatic hydrolysis. Figure 2 presents the changes in softwood and hardwood fibers that occurred during the first $5 \mathrm{~h}$ of hydrolysis.
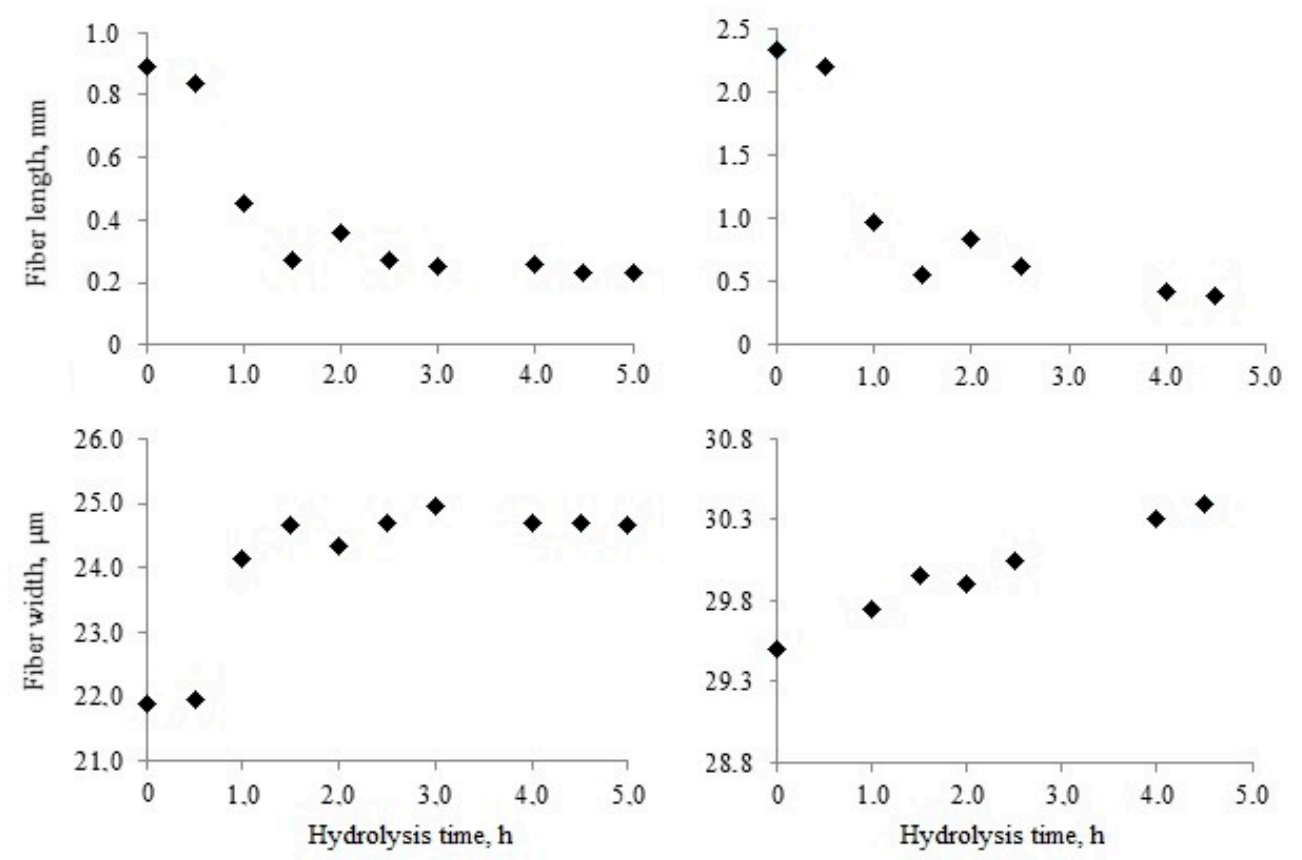

Figure 2. Fiber length and width of bleached hardwood pulp (BHP; left) and bleached softwood pulp (BSP; right) during enzymatic hydrolysis. 
The average length of softwood kraft pulp fibers was almost 2.7 times higher when compared with hardwood fibers. The fiber length decreased during hydrolysis. Enzymatic destruction was the main reason for fiber cutting.

Fiber cross-cutting was the most intensive during the first $1-2 \mathrm{~h}$. Softwood pulp fibers were shortened by almost five times in this period. Hardwood fibers were also shortened, but, to a lesser extent, by three times. The reduction in fiber length improved pulp stirring at the initial stage of hydrolysis. It took place when the average fiber length was about $0.3-0.5 \mathrm{~mm}$. Later the average fiber length continued to decrease, but to a much lesser extent. After $5 \mathrm{~h}$ of hydrolysis, the decrease of fiber length was $84 \%$ for softwood pulp and $74 \%$ for hardwood pulp. Despite this, softwood pulp fiber remained approximately 1.5 times longer than hardwood fiber.

Simultaneously with fiber shortening, the width increased due to swelling. The destruction of fiber surface layers was necessary for the swelling. It occurred under the action of Penicillium verruculosum enzyme complex. The action of cellulase and xylanase first destroyed the outer fiber layers that were most accessible to hydrolysis, leading to a partial loosening of their structure.

Softwood and hardwood pulp fibers swelled most intensively in the first hour of hydrolysis. However, the degree and rate of swelling were different for these fibers. Hardwood libriform fibers have thicker cell walls $(5.00 \mu \mathrm{m})$ when compared with these of the water-conducting softwood tracheids of early $(2.01 \mu \mathrm{m})$ and late $(4.16 \mu \mathrm{m})$ wood tissues [44]. A significant difference in fiber cell wall thickness maintained after kraft pulping. The hardwood pulp fiber width increased quickly in the first hour of hydrolysis, but then changed slightly. The fiber width increased by $12 \%$ after $5 \mathrm{~h}$ of hydrolysis. This effect led to swelling of the largest $S_{2}$ layer.

Softwood pulp fiber swelling was gradual for $5 \mathrm{~h}$. The increase in fiber width did not exceed 3\% in this period. Differences in the morphology and chemical composition of fiber cell walls could be a factor in such different behavior. Hardwood pulp fiber contains much more adsorbed xylan on the surface. Its rapid destruction in the first stages of hydrolysis could have "open the surface" and led to more intensive swelling. Besides, softwood pulp, unlike hardwood, has a wider fiber cavity, so cell wall swelling could go toward the center of the fiber [45]. It does not cause increased width and the device does not fix it.

Changes in fiber structure during $1-5 \mathrm{~h}$ of enzymatic hydrolysis were visualized while using an optical microscope (Figure 3).

Kraft fibers have a shape of long cells with pointed or rounded ends. There are many bends and kinks in the fibers. Dislocations often arise after chemical treatment during pulping and bleaching or after the mechanical stress of pulp transporting and mixing [46]. Cutting mainly occurs in fiber dislocations. Dislocations are defined as local changes in cellulose microfibrils of the $\mathrm{S}_{1}$ layer, or in the $\mathrm{S}_{1}$ and $\mathrm{S}_{2}$ layers of the secondary cell wall. This also includes kinks and bends [47]. This fiber cross-cutting phenomenon has been observed and discussed previously [48,49]. More accessible for enzymes, opened and less ordered structures are formed in fiber dislocations due to such structural features. This provides deeper enzyme penetration into dislocations and better binding to cellulose $[47,50]$. This was previously confirmed by the observation of endoglucanases, cellobiohydrolases, and cellulose-binding modules binding at dislocations [46].

Only a few initial shapes of long fibers were detected after $1 \mathrm{~h}$ of hydrolysis. Increasing the hydrolysis time changed the fibers noticeably. Fiber fragments that had many cracks represented BSP. The cell wall structure was "torn off" at the edges. Softwood pulp fibers were fragmented, but the fragment size was quite large. A significant accumulation of small fiber fragments was noticed after 2-3 h of hydrolysis (Figure 3). The fiber fragments obtained after $3 \mathrm{~h}$ of hydrolysis had no significant dislocations. Only small fiber fragments were observed in softwood pulp after $5 \mathrm{~h}$ of hydrolysis. It should be noted that most of the fiber fragments at that time point had neither twists nor bends. The prolonged action of the Penicillium verruculosum enzyme complex led to the disintegration of the fiber surface layers and increased the amount of fines fraction in the pulp. 


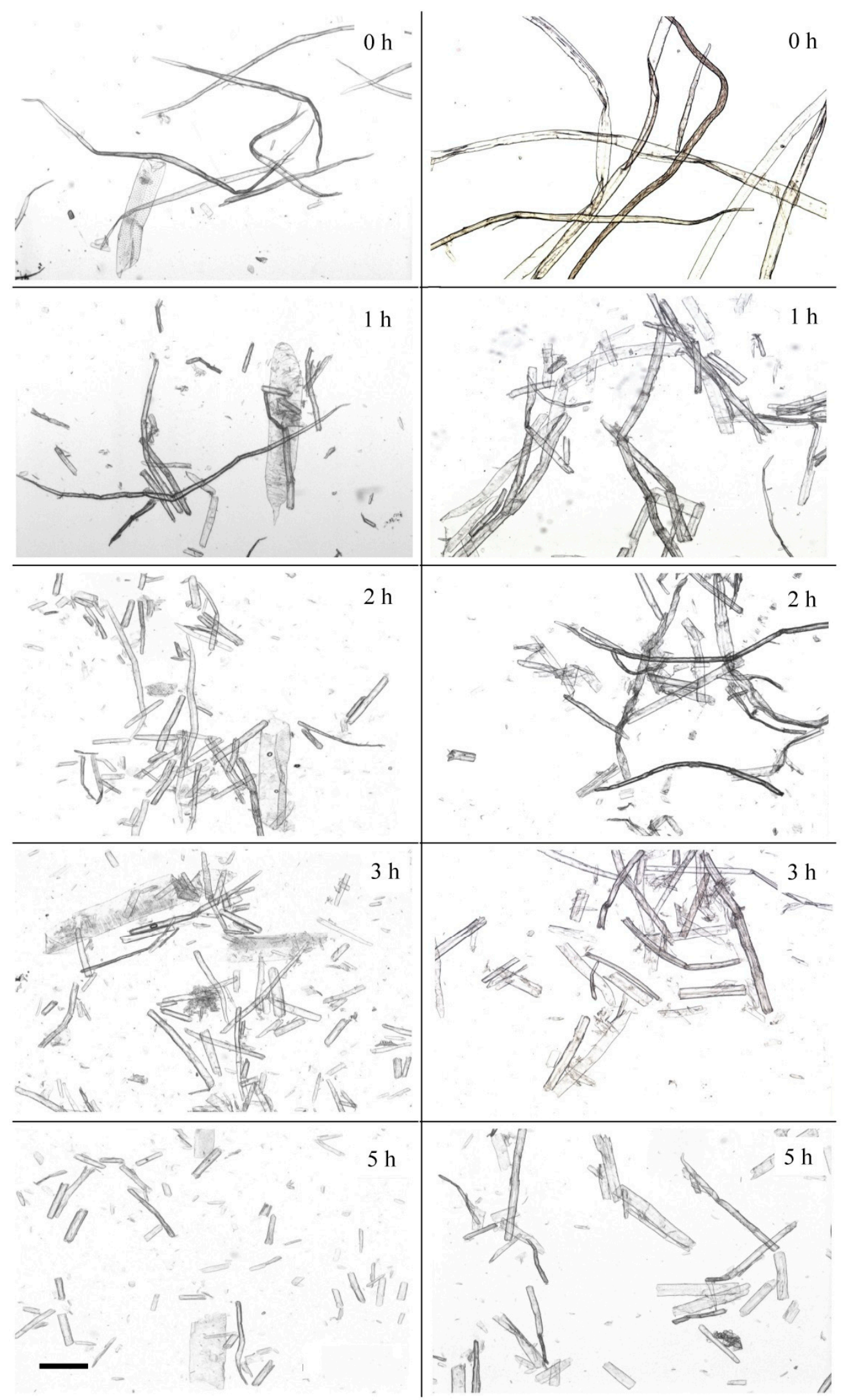

Figure 3. Microscopic images of gradual enzymatic degradation of hardwood (left) and softwood (right) pulp fibers for $5 \mathrm{~h}$. Bar: $0.1 \mathrm{~mm}$. 
Initial hardwood pulp contained thinner and shorter fibers and vessel elements. BHP fibers had bends and twists, like softwood fibers. Significant fragmentation of fibers occurred and multiple breaks were observed after $1 \mathrm{~h}$ of enzyme action. Hardwood pulp fibers were fragmented by enzyme action faster and to a greater extent when compared to softwood pulp. Vessels were also partially destroyed $(5 \mathrm{~h})$, but with less extension than fibers.

\subsection{Behavior of Hardwood Pulp Vessels during Enzymatic Hydrolysis}

Vessels in hardwood perform a conducting function [2,51]. Vessels are built from elements that are joined end-on-end, forming long, continuous tubes [51]. Long vessels of hardwood are destroyed during the kraft process in order to separate short fragments, the length of which is comparable to the fibers. However, the width of the vessel fragments is much larger than the width of the fibers.

These fragments in the composition of BHP are rare, about five fragments of vessels per 1000 fibers (Figure 4). The change in the number of vessels in the bioconversion process was studied while using the L\&W Fiber Tester. Fragments of vessels were more resistant to selected carbohydrase complex than libriform fibers. At the beginning of the enzymatic hydrolysis process $(1-5 \mathrm{~h})$, the ratio of vessel fragments to fibers increased rapidly by about three times (Figure 4). This is because the proportion of fractions of long and medium fibers in enzymatic hydrolysis decreases rapidly, and the amount of fines fraction (less than $0.2 \mathrm{~mm}$ ) increases. When calculating the ratio of vessels and fibers, the fines fraction of fibers is not taken into account.

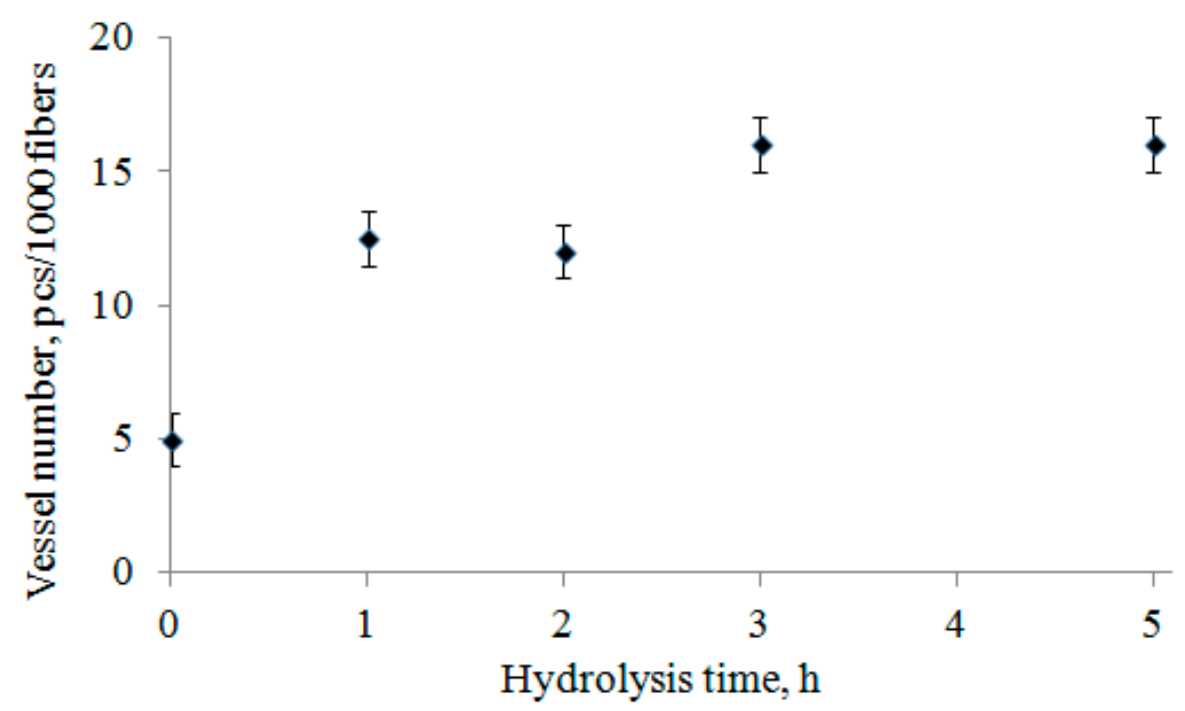

Figure 4. Number of vessels during enzymatic hydrolysis of hardwood pulp.

The cell walls of vessels of birch (Figure 5A) and aspen (Figure 5B) are highly ornamented with pits, the locations of which may differ [51]. The wall structure of vessels is built of three layers of cellulosic fibrils arranged in varying helical angles around the central axis, as in wood fibers. The average thickness of the primary wall of the anatomical elements of hardwood xylem is approximately the same, $0.06-0.07 \mu \mathrm{m}$ (together with middle lamella) [2,20]. At the same time, the $S_{2}$ layer in vessels is the thinnest in comparison with other cell types. For this reason, the average thickness of the vessel's cell walls is also the thinnest, $1.00 \mu \mathrm{m}$, whereas, in libriform fibers, it is $5.00 \mu \mathrm{m}[2,44]$. While using the UV microscopy method, it was found that the content of lignin in the vessels of white birch (Betula papyrifera) was higher (24-28\%) than in the libriform fibers (19-22\%) [52]. In addition, vessel lignin is closer in composition to lignin in coniferous wood.

After the kraft process and bleaching, the fragments of hardwood pulp vessels looked slightly modified (Figure 5C). During enzymatic hydrolysis, the fiber structure was intensively destroyed, but 
the vessel fragments retained their walls for 3-8 h of enzymatic hydrolysis (Figure 5D,E). A portion of the vessel wall is observed, even after enzymatic hydrolysis for $48 \mathrm{~h}$ (Figure 5F).
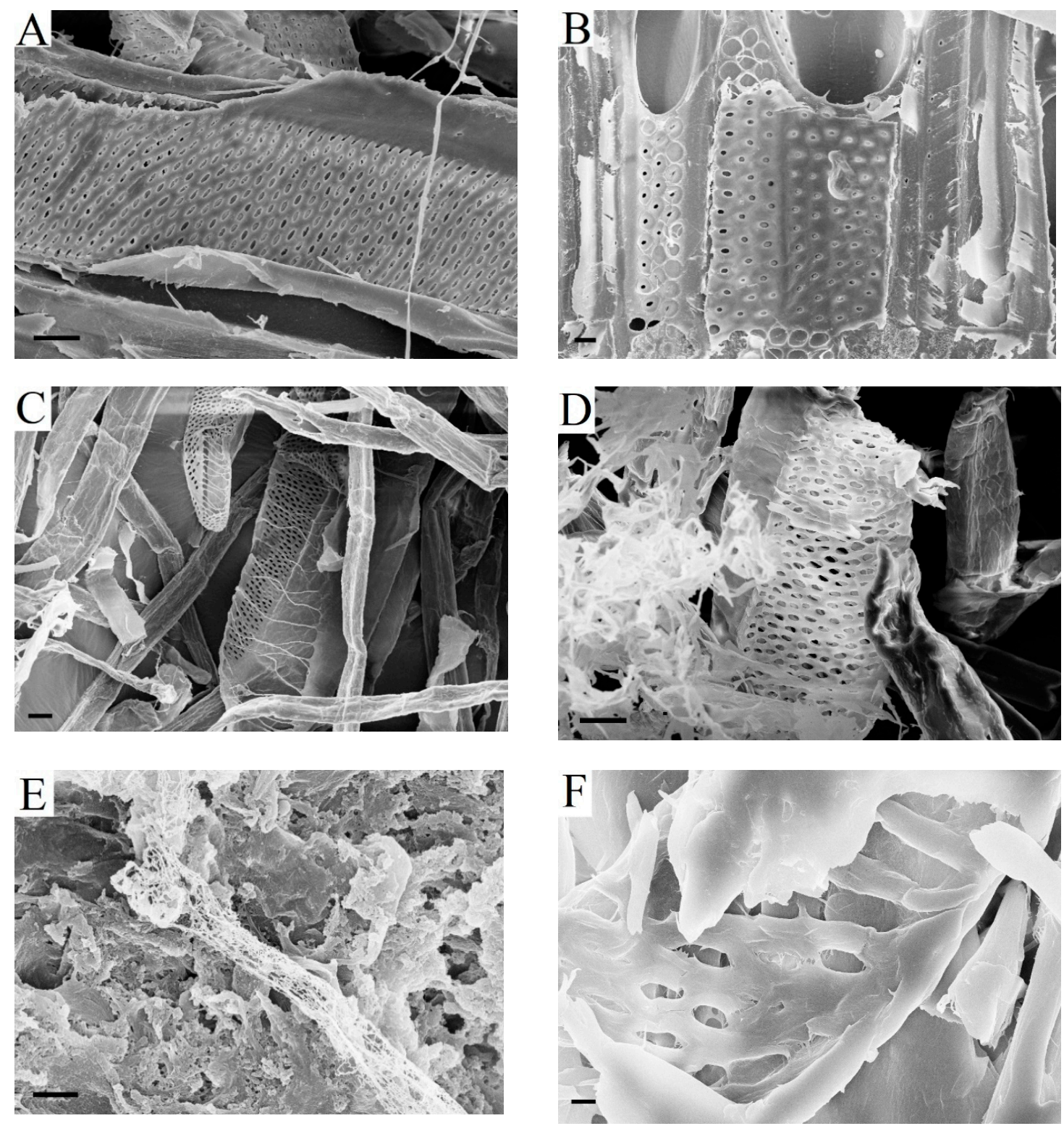

Figure 5. Wood vessels and BHP vessels before and after enzymatic hydrolysis: (A) birch wood vessel wall with numerous pits; (B) aspen wood vessels with numerous pits of various shapes in the walls; (C) vessels fragments of the BHP with numerous pits; (D) vessel fragment of BHP after $3 \mathrm{~h}$ of enzymatic hydrolysis; (E) vessel fragment of the BHP after $8 \mathrm{~h}$ of enzymatic hydrolysis; and, (F) residue of the vessel wall of BHP after $48 \mathrm{~h}$ of enzymatic hydrolysis. Bars: $(\mathbf{A}, \mathbf{B}, \mathbf{D}, \mathbf{E})-10 \mu \mathrm{m},(\mathbf{C}, \mathbf{F})-1 \mu \mathrm{m}$.

However, the negative effect of high lignin content in vessels on enzymatic hydrolysis is practically excluded when using bleached pulp as a substrate. The reason for the high resistance of vessel walls to chemical and enzymatic degradation remains unclear. The chemical composition of vessel walls has not been studied enough. Perhaps the primary walls of vessels contain more xyloglucan than the primary walls of fibers. It is established that this hemicellulose polysaccharide can strongly limit the biocatalytic effect of cellulases [53]. 


\subsection{Role of Fiber Pits in Kraft Pulp during Enzymatic Hydrolysis}

Pits appear in the cell walls of woody fibers after the formation of the $S_{1}$ layer [31]. There are two main types of pits: simple and bordered pits [51]. Simple pits of libriform fibers are slit-shaped and small in size (Figure 6A). Figure 6B shows the bordered pits of tracheids partially destroyed after cryomechanical treatment with liquid nitrogen.
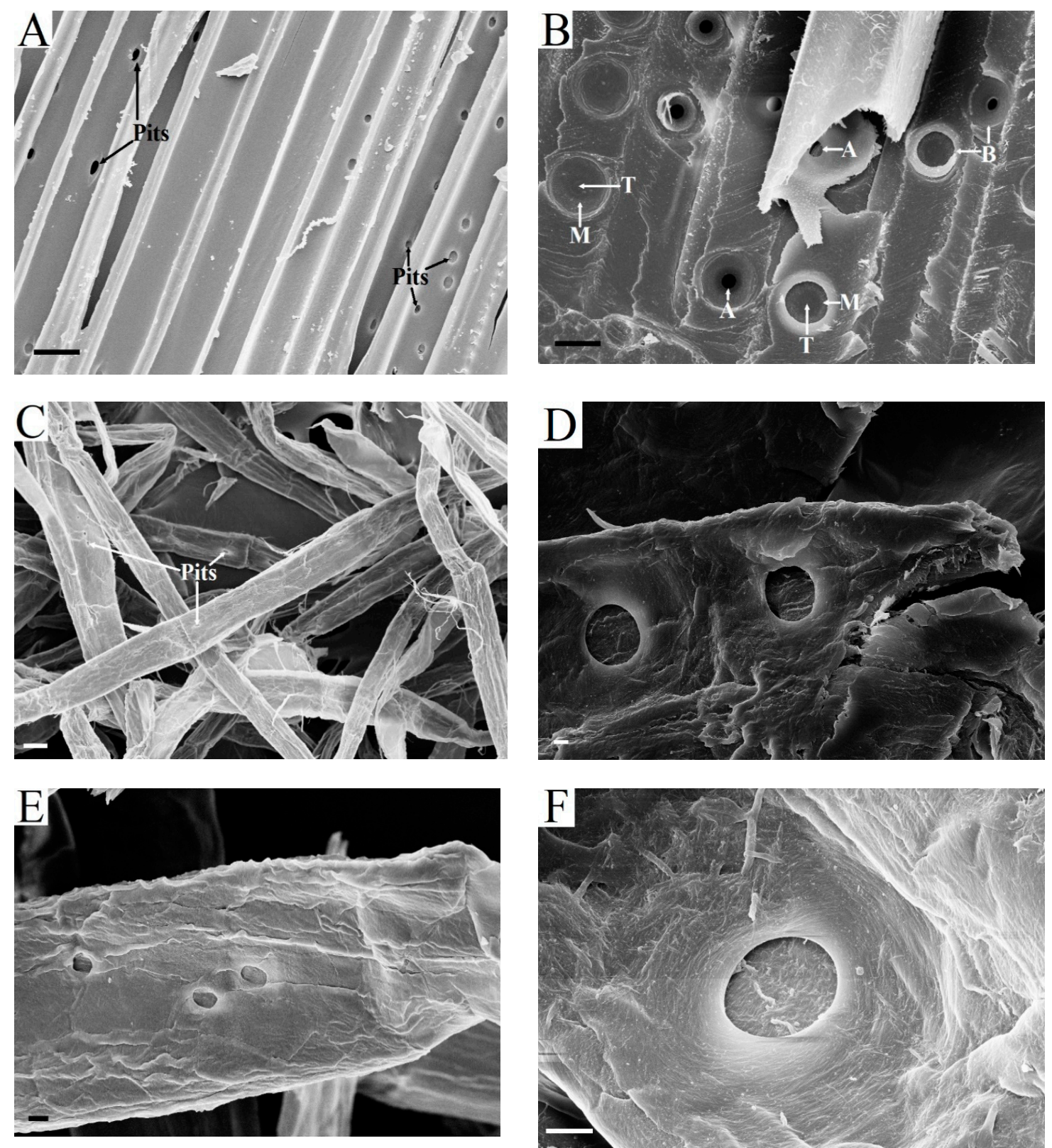

Figure 6. Pits of wood and kraft pulp fibers: (A) simple pits in libriform fibers; (B) bordered pits in tracheids of conifers; (C) pits in hardwood kraft pulp fibers; (D) pits in fibers of softwood kraft pulp after $3 \mathrm{~h}$ of enzymatic hydrolysis; and, (E) pits in fibers of hardwood kraft pulp after $3 \mathrm{~h}$ of enzymatic hydrolysis; (F) pit in fiber of softwood kraft pulp after $5 \mathrm{~h}$ of enzymatic hydrolysis. A-aperture, B-border, BP-bordered pit, $\mathrm{M}$-margo, T—torus. Bars: $(\mathbf{A}-\mathbf{C})-10 \mu \mathrm{m} ;(\mathbf{D})-1 \mu \mathrm{m} ;(\mathbf{E}, \mathbf{F})-2 \mu \mathrm{m}$.

The separation of the wood matrix into individual fibers during kraft pulping leads to the destruction of pit membranes. As a result, pit apertures are open in the walls of kraft fibers (Figure 6C-F). Through these holes, enzymes can penetrate into the lumen and attack the walls of 
the fibers from the inside. It is obvious that large pits of softwood kraft fibers are more effective for transporting enzymes than very narrow pits of hardwood pulp fibers. As far as we know, the role of pits of kraft fibers during enzymatic hydrolysis has not been discussed before. It is important to note that enzyme transport through the pits is possible immediately after the beginning of enzymatic hydrolysis and it does not depend on the degree of destruction of the surface layers of fibers or their cutting in the transverse direction. The pit cavities localized in the walls of kraft fibers remained for 3-5 h of enzymatic hydrolysis (Figure 6). In addition, the structure of the cell wall in the presence of pits has obvious defects. For this reason, it cannot be excluded that bends in the fibers mainly occur in the areas of pit localizations.

\subsection{Changes of kraft fiber structure during enzymatic hydrolysis}

Long pulp fibers were cut into small fragments during enzymatic hydrolysis, as shown in Figure 2. Changes of fiber structure during hydrolysis at the micro level have been investigated in a number of studies [46-49,54-56]. As a result, a two-stage hydrolysis mechanism was proposed [46,56]. The first stage is a quick initial enzyme cross-cutting of the fiber into small particles. The second stage is swelling of fiber parts and their gradual destruction by peeling/erosion of the surface. However, it is believed that these stages are not clearly separated in time and they can take place simultaneously.

Figure 7 shows variants of kraft fiber destruction at an early stage of hydrolysis.
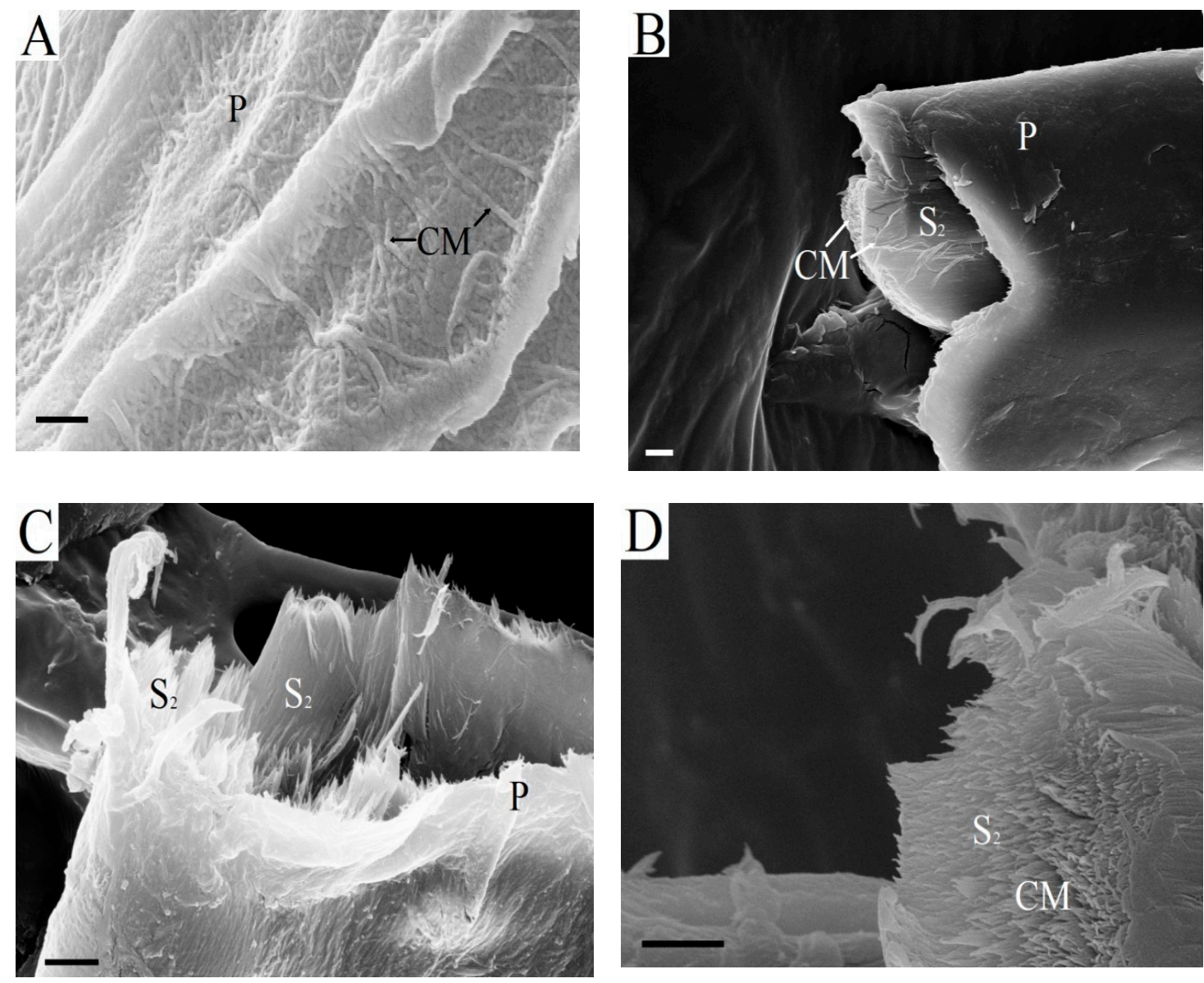

Figure 7. Cont. 

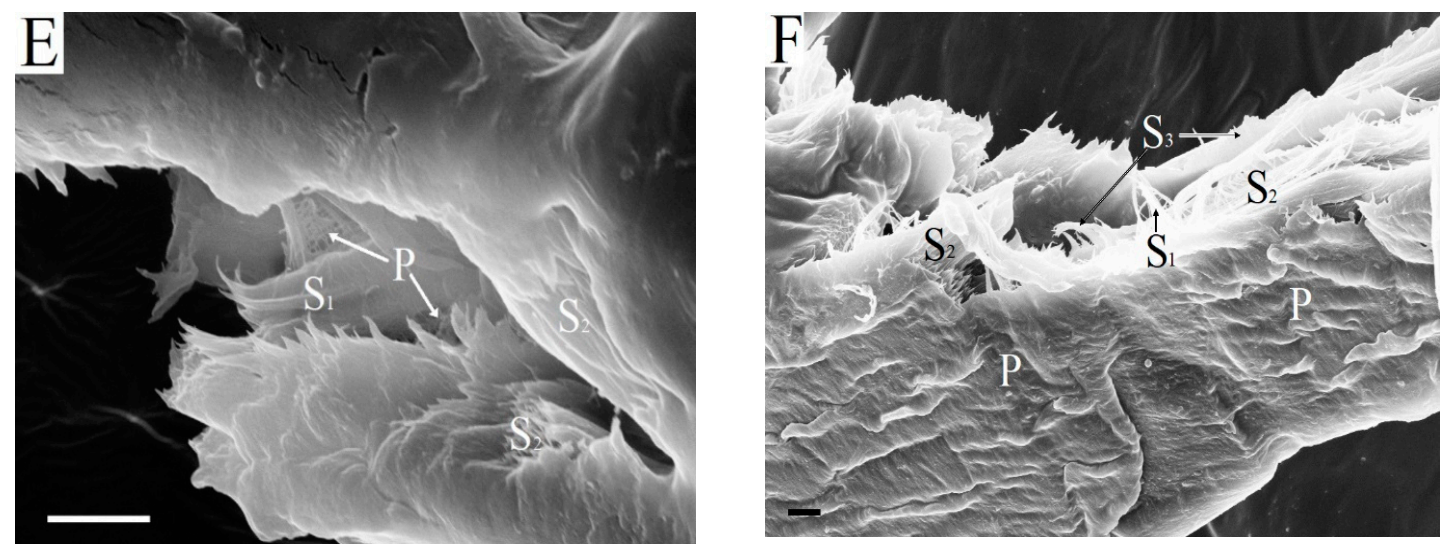

Figure 7. Kraft fibers at different stages of enzymatic degradation: (A) fiber of BSP with preserved primary wall; (B) cross-cutting of the BSP fiber after $1 \mathrm{~h}$ of enzymatic hydrolysis; (C) cross-cutting of the BSP fiber after $3 \mathrm{~h}$ of enzymatic hydrolysis; (D) the cellobiohydrolase catalyzes the hydrolysis of cellulose microfibrils of the $S_{2}$ layer; (E) primary wall fragments were preserved during enzymatic degradation of $S_{1}$ layer and $S_{2}$ layer; and, $(F)$ enzymatic degradation of the surface of BHP fiber after $5 \mathrm{~h}$ of enzymatic hydrolysis. $\mathrm{CM}$-cellulose microfibrils, $\mathrm{P}$ - primary wall, $\mathrm{S}_{1}-\mathrm{S}_{1}$ layer, $\mathrm{S}_{2}-\mathrm{S}_{2}$ layer. Bars: (A) $-200 \mathrm{~nm}$; (B-F) $-1 \mu \mathrm{m}$.

The fiber morphology and topochemical processes occurring on its surface determine the enzymatic destruction of the fiber. The enzymes of Penicillium verruculosum enzyme complex can immediately penetrate directly into the fiber through large pits in the cell walls (Figure 6) and begin enzymatic destruction of the $S_{2}$ layer. It was found that the primary wall, which is resistant to the action of cellulases, is partially preserved after the kraft process and bleaching (Figure 7A). The outer layer of kraft fibers of bleached pulp is open and available for the action of enzymes of the Penicillium verruculosum enzyme complex. The destruction of surface-located xylan is faster. The cellulose macromolecules are broken into separate fragments mainly under the action of endo- $\beta$-1,4-glucanases. The destruction of surface fiber layers leads to fiber swelling. Fiber cutting occurs simultaneously with the swelling of fiber fragments.

Figure 7B shows the destruction of the fiber at the cross-cutting site at $1 \mathrm{~h}$ of hydrolysis. The outer layer of the BSP fiber does not yet have defects on the surface. The smooth end of a cross-cutting fiber fragment is observed. Increasing the number of fiber breaks provides easy access to the $S_{1}$ and $S_{2}$ layers for enzymes from transverse directions. The enzymatic destruction increases at the site where the fiber breaks (Figure 7C). Fiber fragments are formed with an open surface of the $S_{1}$ and $S_{2}$ layers in the cut zone.

Cellulose microfibrils of the $S_{2}$ layers that were oriented along the fiber axis were hydrolyzed by cellobiohydrolases (Figure 7D). This is the main direction of biocatalytic destruction of the kraft fiber structure. Earlier it was suggested that fiber particle ends are more reactive to enzymatic hydrolysis when compared with the central part [46]. However, primary wall fragments with characteristic randomly oriented cellulose microfibrils were still preserved in the fiber, even when significant degradation of the $S_{1}$ and $S_{2}$ layers has taken place (Figure 7E). BHP fiber has the least durable surface layer due to its high xylan content, which is rapidly destroyed at the beginning of hydrolysis. Figure 7F shows significant enzymatic degradation of the surface of BHP fiber after $5 \mathrm{~h}$ of enzymatic hydrolysis. Thus, after fibers are cut into separate fragments and form new ends of cross-cutting fiber fragments, there is preferential enzymatic destruction of the largest $\mathrm{S}_{2}$ layer, which is supplemented by hydrolysis of the $S_{1}$ layer and partially primary wall.

The SEM images of fibers at different enzymatic hydrolysis stages did not reveal qualitative differences between the hydrolysis mechanisms for the tested substrates (Figure 8). The process followed the same stages for all pulp samples according to the sequence that is described above. 

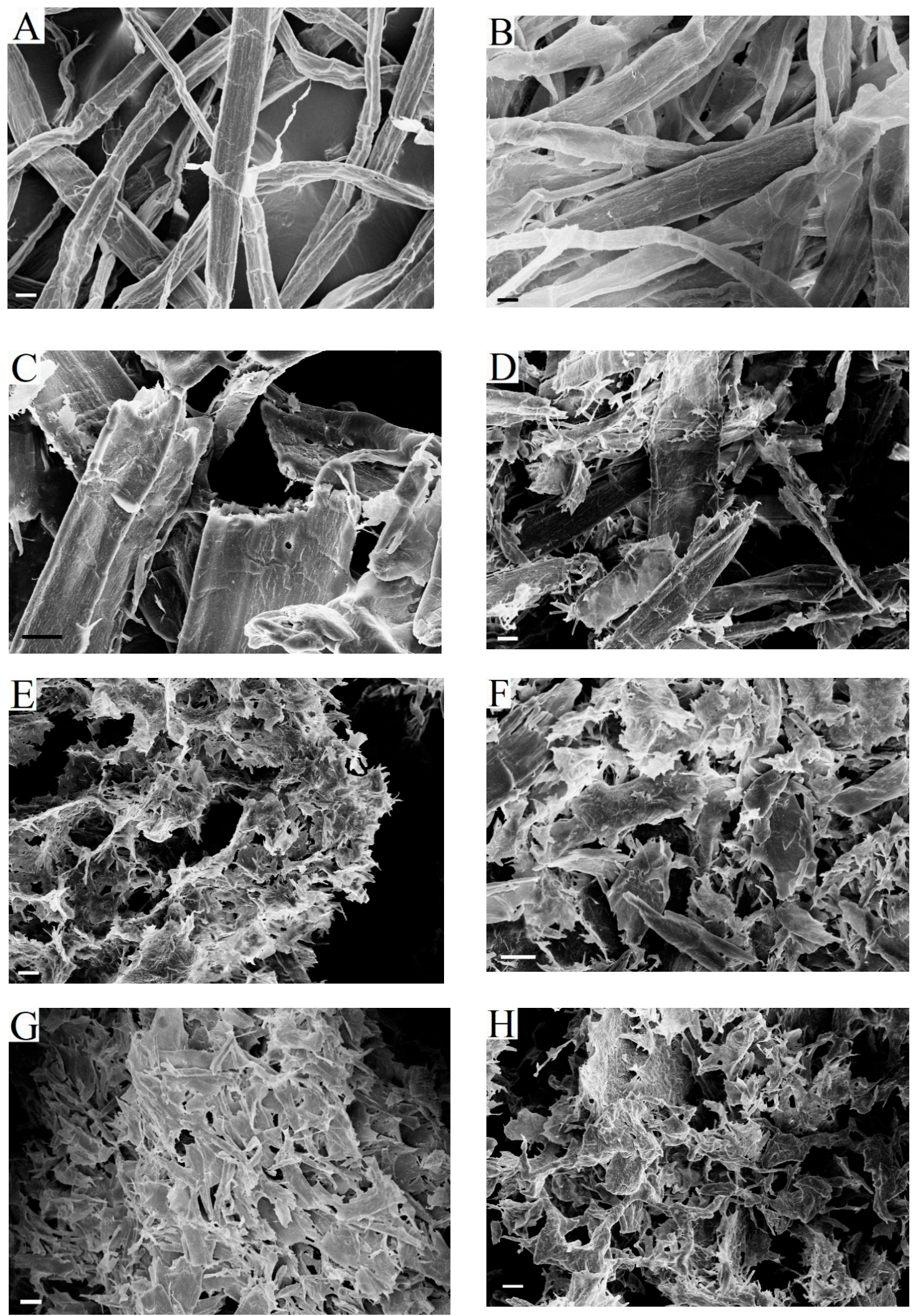

Figure 8. Fibers of BHP and SHP before and after enzymatic hydrolysis: (A) fibers of BHP; (B) fibers of BSP; (C) the BHP fiber after $3 \mathrm{~h}$ of enzymatic hydrolysis; (D) the BSP fiber after $3 \mathrm{~h}$ of enzymatic hydrolysis; (E) the BHP fiber after $8 \mathrm{~h}$ of enzymatic hydrolysis; (F) the BSP fiber after $8 \mathrm{~h}$ of enzymatic hydrolysis; (G) the BHP fiber after $24 \mathrm{~h}$ of enzymatic hydrolysis; and, (H) the BSP fiber after $24 \mathrm{~h}$ of enzymatic hydrolysis. Bars: (A-H) $-10 \mu \mathrm{m}$. 
Figure 8 A,B show BHP and BSP fibers before enzymatic hydrolysis. Fiber fragments obtained after $3 \mathrm{~h}$ of hydrolysis (Figure $8 \mathrm{C}, \mathrm{D}$ ) had new ends that were formed during cross-cutting. The formation of new ends during fiber cross-cutting gives more new active sites for cellobiohydrolase.

Large fiber fragments were no longer observed after $8 \mathrm{~h}$ of enzymatic hydrolysis in hardwood pulp (Figure 8E). The deep degradation of fibers and unwrapped fiber fragment formation were noticed. At the same time, severely shortened and damaged fibers were still present in BSP (Figure 8F). More intensive surface erosion and swelling of BHP fibers were the reason for this difference. This is consistent with the previously noted more intensive increase of BHP fiber width during hydrolysis (Figure 2).

The formation of small fiber fragments with a smooth surface was observed after $24 \mathrm{~h}$ of hydrolysis. The particle size in hardwood pulp (Figure 8G) was smaller than in softwood pulp (Figure $8 \mathrm{H}$ ). It was proposed in order to evaluate the possibility of using non-hydrolysable residues as cellulose powder [57].

It was established that the hydrolysis rate decreases significantly [54] in the last stages of enzyme hydrolysis. It happens despite decreased particle size and increased specific surface of the unhydrolyzed residue. Such a slowdown in hydrolysis rate can happen for various reasons, including the presence of components, for which there are no specific biocatalysts in the Penicillium verruculosum enzyme complex, the presence of recalcitrant to hydrolysis components of cell walls, and the accumulation of hydrolysis products that are inhibitors of individual enzymes.

\subsection{Characteristics of Residue of Hardwood Bleached Kraft Pulp after Prolonged Enzymatic Hydrolysis}

The residue (yield was $16 \%$ of BHP) after $72 \mathrm{~h}$ of enzymatic hydrolysis was fractionated while using a specially designed separation funnel. Two fractions were isolated that differed in structure. A microscopic study allowed for us to establish the morphological characteristics of each one (Figure 9).

The top fraction was deeply destroyed fragments of pulp fibers (Figure 9A,B). The top fraction contained small flat fragments of a highly degraded secondary cell wall. The crystallinity degree was determined on an XRD-7000S diffractometer (Shimadzu), according to the procedure described by Chukhchin et al. 2016 [58]. A linear relationship between the ratio of crystalline and amorphous parts of various materials was obtained, which confirmed the presence of additivity when evaluating this parameter. The proposed method allows for us to objectively evaluate and compare the crystallinity degree of cellulose of various modifications and degrees of destruction. The crystallinity degree of the components of top fraction was low $(28.9 \%)$. This is typical for pulp residues after prolonged hydrolysis [17]. They were structured in the form of film-like fragments. The crystallinity degree of the components of the bottom fraction (37.6\%) was similar to the crystallinity of BHP (40.7\%) [58]. The bottom fraction (Figure 9C,D) contained fragments with a chaotic arrangement of cellulose microfibrils. These were mostly residues of the destroyed primary cell wall. It is established that the primary walls of woody fibers are resistant to enzymatic hydrolysis [44]. This was experimentally confirmed by studying pit formation in the walls of tracheids and fibers of libriform [30]. The action of endo-1,4- $\beta$-glucanases delivered by exosomes led to the formation of pit contours in the $S_{1}$ layer of the secondary wall. However, the cellulose microfibrils of the primary walls of two neighboring cells were resistant to the action of plant endo-1,4- $\beta$-glucanases and preserved as pit membranes. Microfibrils of the primary walls, together with xyloglucan, form a cellulose-xyloglucan network $[59,60]$. The xyloglucan component of the xyloglucan-cellulose complex was much more accessible to enzymatic hydrolysis by Streptomyces endoglucanases than cellulose microfibrils [53]. Evidently, cellulose microfibrils of the primary wall are likely protected from cellulase action by xyloglucan. 

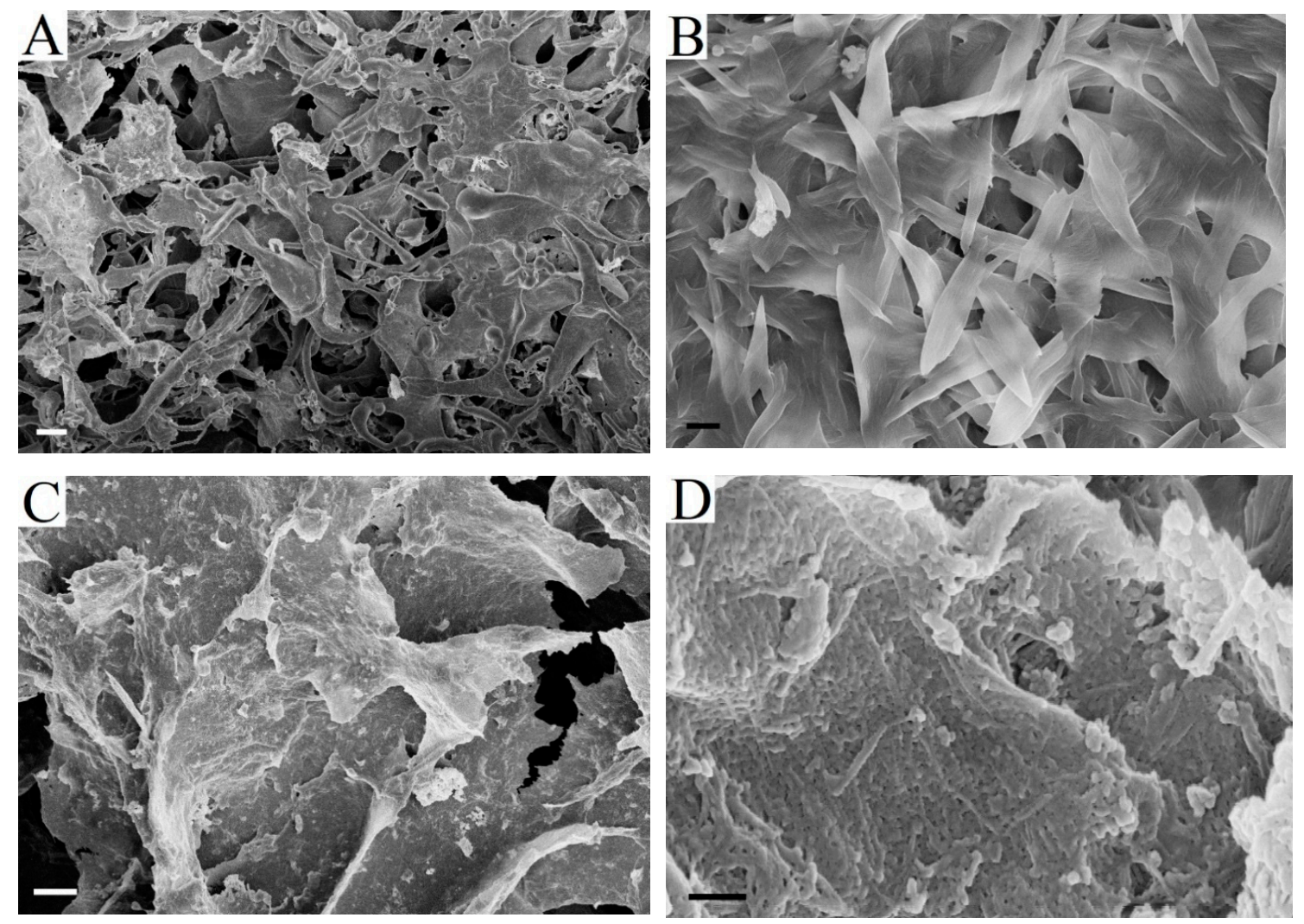

Figure 9. Images of cellulose residue fractions after enzymatic hydrolysis of BHP over $72 \mathrm{~h}$ : $(\mathbf{A}, \mathbf{B})$ the top fraction of cellulose residue in different magnification; $(\mathbf{C}, \mathbf{D})$ the bottom fraction of cellulose residue in different magnification. Bars: (A) $-10 \mu \mathrm{m}$; (B) $-1 \mu \mathrm{m}$; (C) $-10 \mu \mathrm{m}$; and, (D) $-200 \mathrm{~nm}$.

\subsection{Analysis of Bleached Pulp Hydrolysates}

Enzymatic hydrolysis of kraft pulps produced glucose and xylan degradation products, because cellulases and xylanase are the main enzymes of the Penicillium verruculosum complex. We studied sugar accumulation during bleached pulp hydrolysis at initial stages of hydrolysis (up to $24 \mathrm{~h}$ ) at pulp concentrations of $5 \%$ and $10 \%$. Glucose is the main sugar formed during the hydrolysis of kraft pulp. The accumulation of glucose in hydrolysates occurred quickly during the first hours and then slowed down later. The glucose concentration became noticeably higher for BSP as compared to BHP after $6 \mathrm{~h}$ of hydrolysis (Figure 10). For BSP hydrolysates, it was 29 and $46 \mathrm{~g} / \mathrm{L}$, and, for hardwood hydrolysates, it was 21 and $35 \mathrm{~g} / \mathrm{L}$ after $24 \mathrm{~h}$ of hydrolysis at 5 and $10 \%$ mass concentration, respectively. A lower glucose yield from BHP when compared to BSP was noted earlier in this study. It was mainly due to lower cellulose content in BHP.

An increase in sugar concentration in hydrolysates can lead to the inhibition of enzymes. It was previously described that cellobiose inhibits cellulases [61]. However, in our experiments, we applied high level of cellobiase activity that prevented the accumulation of cellobiose in kraft pulp hydrolysates.

Xylose, xylobiose, and xylooligosaccharides represented xylan degradation products of hydrolysates. Chromatographic analysis of sugars showed high concentrations of xylan destruction products, xylose and xylobiose. After $24 \mathrm{~h}$ of hydrolysis, the amount of xylobiose was higher when compared with xylose for both BHP and BSP (Figure 11). It could be due to a xylanase activity of Penicillium verruculosum enzymes complex. 


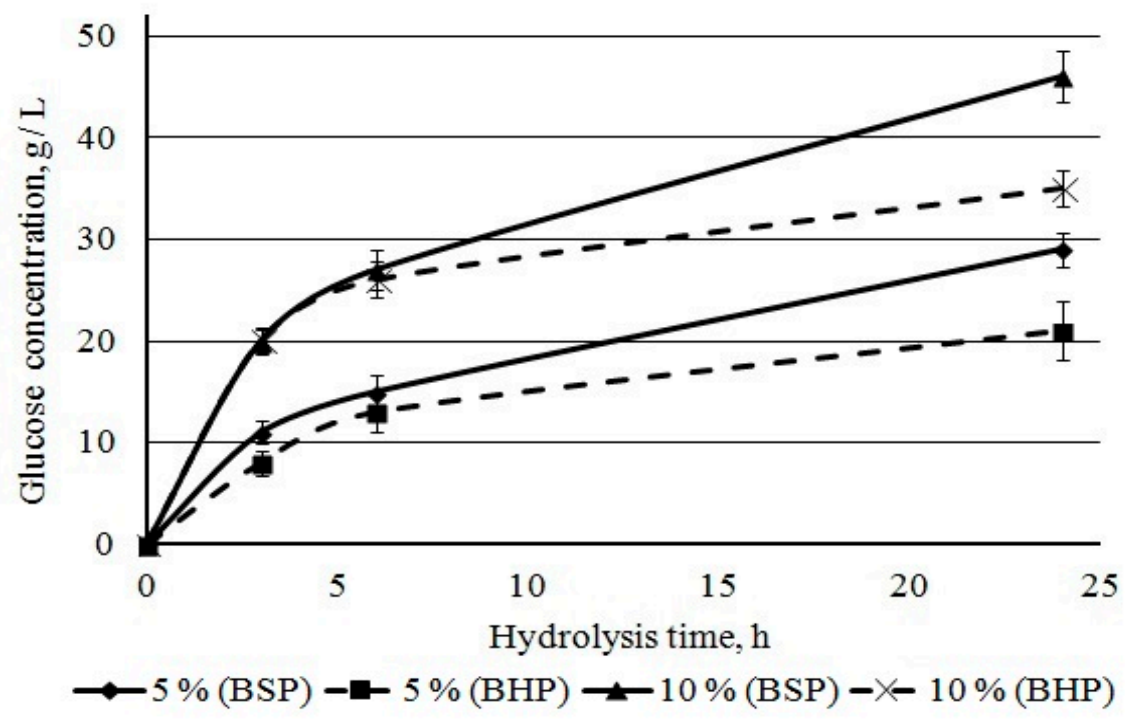

Figure 10. Glucose concentration in pulp hydrolysates during $24 \mathrm{~h}$ of hydrolysis.

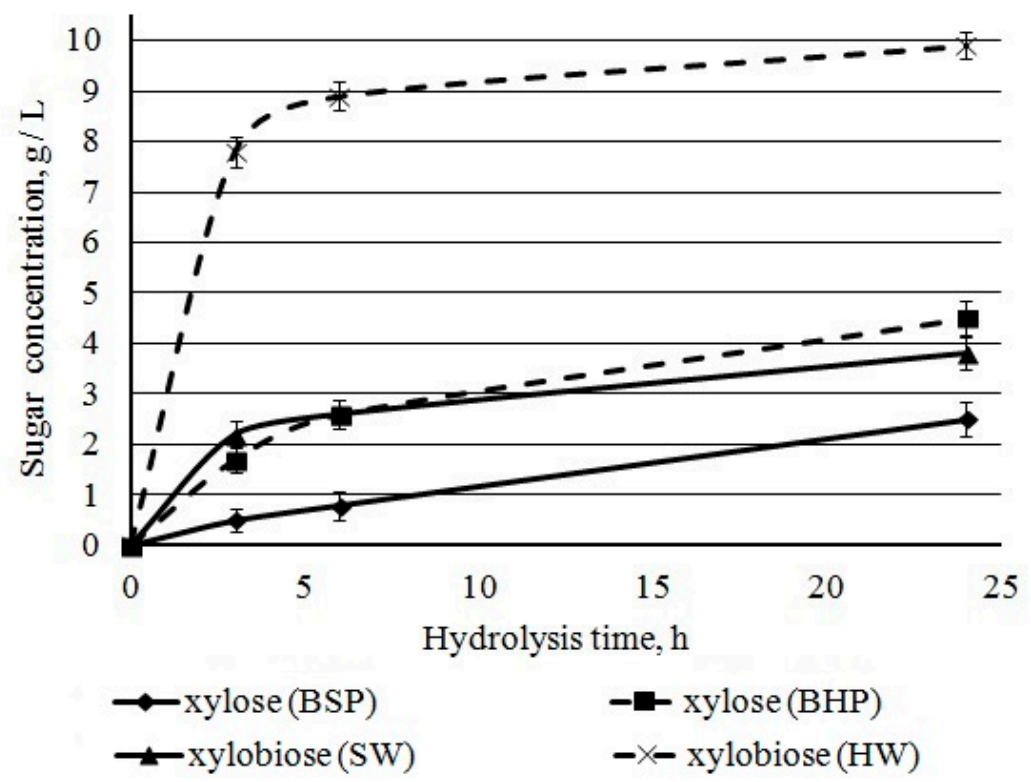

Figure 11. Concentration of xylose and xylobiose in pulp hydrolysates during $24 \mathrm{~h}$ of hydrolysis.

The distribution of xylan in kraft fibers promoted fast xylan hydrolysis. This surface xylan is more accessible for Penicillium verrucolosum xylanase. It was found that the surface layer of BHP had xylan and cellulose contents of $44.4 \%$ and $54.7 \%$, respectively [62]. The mass ratio of xylan/cellulose of our BHP was 0.27 [17], corresponding to the potential mass ratio xylose/glucose in hydrolysates of 0.29. During hydrolysis, the following xylose + xylobiose/glucose ratios were obtained: 0.47 after $3 \mathrm{~h}, 0.43$ after $6 \mathrm{~h}$, and 0.41 after $24 \mathrm{~h}$. This confirms that xylan was rapidly hydrolyzed when compared to cellulose. The surface layer of BSP had xylan and cellulose contents of $12.7 \%$ and $81.1 \%$, respectively [62]. The inner layer of BSP had a $20 \%$ less xylan than the surface layer. The mass ratio of xylan/cellulose of our BSP was 0.093 [17], corresponding to the potential mass ratio xylose/glucose in hydrolysates of BSP 0.095 . However, during hydrolysis the xylose + xylobiose/glucose ratio was 0.13-0.14. Thus, xylan and cellulose are hydrolyzed in equal proportions. It is necessary to include 
mannanase in the composition of Penicillium verruculosum enzyme complex and increase the proportion of cellobiohydrolases to accelerate the enzymatic hydrolysis of BSP.

The xylan conversion that was calculated from xylose and xylobiose concentrations was about $60 \%$ and $80 \%$ for hardwood and softwood pulp, respectively. The incomplete hydrolysis is related to the presence of resistant xylan in cellulose crystalline parts [63] and xyloglucan in the fiber wall [64].

Xylobiose was intensively accumulated during the first hours of hydrolysis; at the same time, the rate of xylose accumulation remained relatively constant during the first $24 \mathrm{~h}$. A high concentration of xylobiose can inhibit cellulases more strongly than xylose [65]. The inhibition of Thermoascusaur antiacus cellobiohydrolase I and Trichoderma reesei cellobiohydrolase II with xylobiose and xylotriose has been demonstrated [66-68]; relevant inhibition was observed at oligosaccharide concentration over $2 \mathrm{~g} / \mathrm{L}$. In our study, this concentration was already achieved at the first hour of hardwood pulp hydrolysis.

Thus, the lower conversion for BHP as compared to BSP is related, first of all, to inhibition by a high concentration of xylobiose, released in the first hours of hydrolysis and remaining high. The determined relations allow for us to reasonably conclude that enzyme complexes for BHP should be enriched with $\beta$-xylosidase (xylobiase) hydrolyzing xylobiose.

The positive effect of high substrate concentration on the enzymatic hydrolysis efficiency $(10 \%)$ on pulp has been established; sugar concentration of $50 \mathrm{~g} / \mathrm{L}$ was achieved by acceptable enzyme dosage of $10 \mathrm{FPU} / \mathrm{g}$ after $24 \mathrm{~h}$ of hydrolysis.

\section{Material and Methods}

\subsection{Substrates}

The substrates included industrial samples of never-dried softwood and hardwood kraft pulps produced from spruce and a 1:1 aspen/birch mixture, respectively. In order to evaluate the effect of pulp hornification on enzymatic hydrolysis, it was also performed with air-dried pulp samples. The kraft pulp composition was determined earlier [17]. Hardwood pulps contained $74.5 \%$ cellulose for USP and $76.0 \%$ for BSP; softwood pulps contained 79.5\% cellulose for USP and $81.0 \%$ for BSP. Unbleached pulps contained $2.1 \%$ (UHP) and 3.0\% (USP) of lignin, measured as non-hydrolyzed residue after two-stage acidic treatment. In hardwood pulps, among noncellulosiccompounds, there was more xylan, $21.5 \%$ for UHP, and $21.9 \%$ for BHP, and less mannan, $0.3 \%$ for USP and BSP. The softwood pulps contained $7.3 \%$ xylan for USP, $7.5 \%$ for BSP, and $6.8 \%$ mannan for USP and $7.0 \%$ for BSP.

\subsection{Enzymes}

The enzymes that were used in this study were cellulolytic enzymes (B1-221-151 and F10) produced by recombinant Penicillium verruculosum strains, which mainly contained endoglucanases, cellobiohydrolases, xylanase (B1-221-151), and cellobiase (F10). The enzyme preparation mix contained the complete set of hemicellulases and cellulases, including cellobiohydrolases 1 and 2 (approximately $40 \%$ of total protein), $\beta$-glucosidase (approximately 25\%), endogluconases 1, 2, and 3 (approximately $10 \%$ ), and xylanase (approximately $2 \%$ ). Approximately $23 \%$ of the enzyme preparation consisted of ballast proteins [12]. Enzyme activity toward different substrates-carboxymethylcellulose (CMC), Avicel, xylan, galactomannan, cellobiose, and Whatman®filter paper No. 1-was determined while using well-established methods [41,69]. Enzymatic activity was determined under the following conditions: $\mathrm{pH} 5.0(0.1 \mathrm{M}$ sodium acetate buffer $)$ and $50{ }^{\circ} \mathrm{C}$. The protein content was determined according to Bradford assay [70]. Penicillium verruculosum enzyme complex carried high levels of CMC-ase, Avicelase, cellobiase, and xylanase activity [18], but low mannanase activity $(<1.0 \mathrm{U} / \mathrm{mg})$. The enzyme dosage was adjusted to give total activity of up to 10 FPU per gram of dry pulp, as in previous research [18]. 


\subsection{Enzymatic Hydrolysis}

The enzymatic hydrolysis of pulp at $5 \%$ and $10 \%$ concentrations was conducted on a laboratory shaker at $50{ }^{\circ} \mathrm{C}$ with constant stirring $(250 \mathrm{rpm}$ ) for $3,6,24,48$, and $72 \mathrm{~h}$. pH was maintained at 5.0 with sodium acetate buffer. Non-hydrolyzed residue was separated from the reaction mixture by centrifugation at $4200 \mathrm{rpm}$ for $15 \mathrm{~min}$. The supernatant was collected and analyzed for sugar and lignin content. The non-hydrolyzed residue was carefully washed with distilled water in order to separate soluble sugars. Washing was performed by sequentially repeating cycles of residue mixing and centrifugation at $4200 \mathrm{rpm}$ for $15 \mathrm{~min}$. After each cycle, the supernatant was gently merged and a fresh portion of distilled water was added. Non-hydrolyzed pulp residue was further analyzed for yield calculation, fractionation, and determination of crystallinity degree, fiber size, and morphology.

\subsection{Non-Hydrolyzed Residue Yield Calculation}

The washed non-hydrolyzed residues were frozen, freeze-dried, and kept at $20^{\circ} \mathrm{C}$ to stabilize moisture content. Subsequently, residues were weighed (air-dry weight) and moisture content (\%) was determined by drying $1 \mathrm{~g}$ samples at $103 \pm 2{ }^{\circ} \mathrm{C}$ to oven-dry weight. Non-hydrolyzed residue yield $\left(\mathrm{Y}_{\text {res }}\right)$ was calculated by the following formula:

$$
\mathrm{Y}_{\text {res }}=\frac{\text { air dry residue weight }(\mathrm{g}) \times(100-\text { moisture content }(\%))}{\text { initial amount of pulp }(\mathrm{g})} \times 100 \%
$$

\subsection{Non-Hydrolyzed Residue Characterization}

\subsubsection{Fiber Size and Morphology Analysis}

All of the residue samples for fiber size and morphology analysis were frozen and freeze-dried. Afterwards, each one was suspended in $400 \mathrm{~mL}$ of distilled water, mixed, and then kept swelling for 15-30 min. Subsequently, $200 \mathrm{~mL}$ of the suspension was analyzed on L\&W Fiber Tester equipment [71]. The fibers were defined as objects more than $0.2 \mathrm{~mm}$ long and less than $0.1 \mathrm{~mm}$ wide. Vessel elements were defined as objects wider than $0.1 \mathrm{~mm}$. The device calculated the number of vessels per thousand detected fibers. Two parallel tests were performed for each sample. Changes in the structure of the fibers in water suspension were also investigated using a Carl Zeiss Axio Imager 2 optical microscope (Oberkochen, Germany).

\subsubsection{Non-Hydrolyzed Residue Fractionation}

A sample of the non-hydrolyzed hardwood pulp residue $(72 \mathrm{~h})$ was fractionated while using a specially designed vertical glass separatory funnel $2 \mathrm{~L}$ in volume, $1 \mathrm{~m}$ in length, and $0.04 \mathrm{~m}$ in diameter. The top end of the column was opened and the bottom end was closed by draining taps to provide slow column draining. The wet residue was mixed with a small amount of water, stirred, and then gently added from the top end to the water-filled column. Over time, the residue separated itself by sedimentation into slowly settling (upper) and rapidly settling (lower) fractions. The lower and upper fractions were collected by taking samples through the drain tap at the bottom end of the funnel. The fractions of residue were dewatered by centrifugation, frozen, and freeze-dried, as described previously.

\subsubsection{Detecting Crystallinity Degree}

The crystallinity degree of freeze-dried fractions was determined on an XRD-7000S diffractometer (Shimadzu, Kyoto, Japan), according to the procedure described by Chukhchin et al. 2016 [58]. The scanning range with respect to angle $2 \theta$ was $10^{\circ}-70^{\circ}$, the scanning rate was $0.5^{\circ} / \mathrm{min}$., the step was 
$0.02^{\circ}$, and the frequency of sample rotation was $30 \mathrm{rpm}$. Two parallel tests were performed for each sample. IC was calculated while using a special formula:

$$
\mathrm{IC}=\frac{\int_{2 \theta=\mathrm{a}}^{\mathrm{b}}\left|\frac{\mathrm{dI}}{\mathrm{d} 2 \theta}\right| \mathrm{d} 2 \theta}{\int_{2 \theta=\mathrm{a}}^{\mathrm{b}} \operatorname{Id} 2 \theta}
$$

where IC is the crystallinity index $\left(\mathrm{deg}^{-1}\right)$; $\mathrm{a}$ and $\mathrm{b}$ are, respectively, the initial and final values of the scanning angle (deg); and, $I$ is the reflection intensity (number of counts).

In order to determine the final value of the crystallinity degree of samples, the result must be compared with the data on an ideal crystal (gold):

$$
\mathrm{X}_{\mathrm{Au}}=\frac{\mathrm{IC}}{\mathrm{IC}_{\mathrm{Au}}} \times 100 \%
$$

where IC is the crystallinity index of the sample $\left(\mathrm{deg}^{-1}\right)$ and $\mathrm{IC}_{\mathrm{Au}}$ is the crystallinity index of gold $\left(\mathrm{deg}^{-1}\right)$.

The result must be compared with the data of microcrystalline cellulose from bacterial cellulose to determine the crystallinity degree $\mathrm{X}_{\mathrm{BC}}$ of the cellulose sample:

$$
\mathrm{X}_{\mathrm{BC}}=\frac{\mathrm{IC}_{\mathrm{Cel}}}{\mathrm{IC}_{\mathrm{BC}}} \times 100 \%
$$

where $\mathrm{IC}_{\mathrm{cel}}$ is the crystallinity index of the cellulose sample $\left(\mathrm{deg}^{-1}\right)$ and $\mathrm{IC}_{\mathrm{bc}}$ is the crystallinity index of microcrystalline cellulose from bacterial cellulose $\left(\mathrm{deg}^{-1}\right)$.

\subsubsection{Scanning Electron Microscopy Analysis}

Scanning electron microscopy (SEM) of initial pulp samples and non-hydrolyzed residues was used to evaluate the destruction of fibers and vessels during enzymatic hydrolysis. Prior to SEM, initial hardwood and softwood pulp fibers and non-hydrolyzed residues were freeze-dried from a water slurry and then sputter-coated with $5 \mathrm{~nm} \mathrm{Pt} / \mathrm{Pd}$ mixture while using a Q150TES spattering system (Quorum, Laughton, East Sussex, UK). The images were obtained using a SIGMA VP instrument (Zeiss, Oberkochen, Germany) operated at $10 \mathrm{kV}$ accelerated voltage.

\subsection{Hydrolysate Analysis}

\subsubsection{Determining Glucose and Reducing Sugars}

Reducing sugars (RS) in the hydrolysates were determined with the Somogyi-Nelson assay [72]. Glucose was determined while using the glucose oxidase-peroxidase assay. The concentrations of minor sugars (cellobiose, xylobiose, xylose, and mannose) were determined using an LC-20 Prominence system (Shim-pack ISA-07/S2504 column, Shimadzu, Kyoto, Japan) with post-column derivatization and fluorometric detection.

\subsubsection{Sugar Yield Calculations}

The yield of glucose $\left(\mathrm{Y}_{\mathrm{G}}\right)$, xylose $\left(\mathrm{Y}_{\mathrm{X}}\right)$, mannose $\left(\mathrm{Y}_{\mathrm{M}}\right)$, and reducing sugars $\left(\mathrm{Y}_{\mathrm{RS}}\right)$ were calculated by the following formulas:

$$
\begin{aligned}
& \mathrm{Y}_{\mathrm{G}}=\frac{\text { glucose in hydrolisate }(\mathrm{g}) \times 0.9}{\text { initial amount of glucan in pulp }(\mathrm{g})} \times 100 \% \\
& \mathrm{Y}_{\mathrm{X}}=\frac{\text { xylose in hydrolisate }(\mathrm{g}) \times 0.88}{\text { initial amount of xylan in pulp }(\mathrm{g})} \times 100 \%
\end{aligned}
$$




$$
\begin{gathered}
\mathrm{Y}_{\mathrm{M}}=\frac{\text { mannose in hydrolisate }(\mathrm{g}) \times 0.9}{\text { initial amount of mannan in pulp }(\mathrm{g})} \times 100 \% \\
\mathrm{Y}_{\mathrm{RS}}=\frac{\text { RS in hydrolisate }(\mathrm{g}) \times 0.9}{\text { initial amount polysaccharides in pulp }(\mathrm{g})} \times 100 \%
\end{gathered}
$$

Glucose was the main sugar in all hydrolysates, so a coefficient of 0.9 for RS yield was chosen.

\subsection{Lignin Content}

Lignin content in hydrolysates was determined while using UV absorbance at $280 \mathrm{~nm}$ wavelength and extinction coefficient of $22.3 \mathrm{~L} /(\mathrm{g} \cdot \mathrm{cm})$, as used in [73], with a UNICO-2800 spectrophotometer (United Products \& Instruments, Dayton, NJ, USA).

\section{Conclusions}

All of the industrial kraft pulps (UHP, USP, BHP, and BSP) are ready substrates for bioconversion using Penicillium verruculosum enzyme complex and give high yields of soluble hydrolysis products. The assumed conditions of enzymatic hydrolysis at a substrate concentration of 5-10\% with a Penicillium verruculosum enzyme complex dosage of $10 \mathrm{FPU} / \mathrm{g}$ of pulp can be acceptable for obtaining hexoses and pentoses in industry.

Even a small amount of kraft lignin (2-3\%) negatively affects the results of enzymatic hydrolysis. The residual lignin in LCC with mannan and xylan reducing the availability of cellulose for cellulases is the main reason for the limited hydrolysis of unbleached kraft pulp. Irreversible changes in the structure of fibers during drying reduce the yield of enzymatic hydrolysis products by $8-14 \%$ from unbleached pulps and by $19-26 \%$ from bleached pulps.

Never-dried BSP showed the best results in glucose and RS yields, while dry USP gave the worst results among the four industrial kraft pulps. This study focused on the bioconversion of never-dried bleached pulps. The availability of fiber cell walls for the enzymes is essential for effective hydrolysis. The enzymes can enter the fiber through large pits in the cell walls. Changes in the morphology and structure of kraft fibers during enzymatic hydrolysis were visualized while using optical and electron microscopy. Fiber cross-cutting occurred at early stages of enzymatic hydrolysis led to the formation of new surfaces for cellulase action. The improved mixing of kraft pulp after rapid shortening of the fibers during enzymatic hydrolysis allows for us to use higher substrate concentrations, $5 \%$ or higher. As a result, the concentration of hexoses and pentoses in the hydrolysate increases and the efficiency of their further processing also increases. Vessels are more resistant to enzymatic hydrolysis than hardwood pulp fibers. Treatment by Penicillium verruculosum enzyme complex leads to the active destruction of the $S_{1}$ and $S_{2}$ layers. The primary walls of kraft fibers and vessels are relatively resistant to enzymatic influences.

Features of the composition of hardwood and softwood kraft pulps require the optimization of the composition of Penicillium verruculosum enzyme complex. In kraft pulp bioconversion, xylan hydrolysis by xylanase yields degradation products that can inhibit the biocatalytic activity of hydrolases. The composition of this complex for hardwood kraft pulp might be improved by adding xylobiase. It is recommended to include mannanase in the composition of Penicillium verruculosum enzyme complex and increase the proportion of cellobiohydrolases to accelerate the enzymatic hydrolysis of softwood kraft pulp.

This study shows the high efficiency of bioconversion of the never-dried bleached kraft pulps. The bioconversion process could be integrated into an existing kraft pulp mill, since it is impractical to transport and store never-dried pulp. The processing of hexoses and pentoses into products with high added value should be organized at the same pulp mill. It is necessary to evaluate the possibility of using non-hydrolysable residues as cellulose powder for rational use in the future. 
Author Contributions: Author Contributions: E.V.N., A.S.A. and A.P.S. designed the research study. E.V.N., D.N.P. and K.Y.T. prepared an original draft. Process of enzymatic hydrolysis performed by A.S.A., A.A.G., I.G.S. and D.N.P. SEM study performed by D.G.C. The crystallinity degree measurements by I.V.T. and D.G.C., A.S.A., E.V.N., D.N.P., I.V.T., D.G.C. and Y.A.S. performed the research and analyzed data as well as discussed, reviewed, and commented on the manuscript. All authors have read and agree to the published version of the manuscript.

Funding: The reported study was funded by RFBR, project number 20-04-00457.

Acknowledgments: The research was performed using instrumentation of Core Facility Center 'Arktika' of Northern (Arctic) Federal University.

Conflicts of Interest: The authors declare no conflict of interest.

\section{References}

1. Adrio, J.L.; Demain, A.L. Microbial Enzymes: Tools for Biotechnological Processes. Biomolecules 2014, 4, 117-139. [CrossRef]

2. Ek, M.; Gellerstedt, G.; Henriksson, G. Wood Chemistry and Biotechnology; Walter de Gruyter: Berlin, Germany, 2009; Volume 1.

3. Alvira, P.; Tomás-Pejó, E.; Ballesteros, M.; Negro, M. Pretreatment technologies for an efficient bioethanol production process based on enzymatic hydrolysis: A review. Bioresour. Technol. 2010, 101, 4851-4861. [CrossRef]

4. Xu, H.; Li, B.; Mu, X. A review of alkali-based pretreatment to enhance enzymatic saccharification for lignocellulosic biomass conversion. Ind. Eng. Chem. Res. 2016, 55, 8691-8705. [CrossRef]

5. Sun, S.; Sun, S.; Cao, X.; Sun, R. The role of pretreatment in improving the enzymatic hydrolysis of lignocellulosic materials. Bioresour. Technol. 2016, 199, 49-58. [CrossRef] [PubMed]

6. Berlin, A.; Gilkes, N.; Kurabi, A.; Bura, R.; Tu, M.; Kilburn, D.; Saddler, J. Weak Lignin-Binding Enzymes. Appl. Biochem. Biotechnol. 2005, 121, 163-170. [CrossRef]

7. Liu, H.; Sun, J.; Leu, S.Y.; Chen, S. Toward a fundamental understanding of cellulase-lignin interactions in the whole slurry enzymatic saccharification process. Biofuels Bioprod. Biorefining 2016, 10, 648-663. [CrossRef]

8. Ek, M.; Gellerstedt, G.; Henriksson, G. Pulping Chemistry and Technology; Walter de Gruyter: Berlin, Germany, 2009; Volume 2.

9. Van Heiningen, A. Converting a kraft pulp mill into an integrated forest biorefinery. Pulp Pap. Can. 2006, $107,38-43$.

10. Contreras, F.; Pramanik, S.; Rozhkova, A.M.; Zorov, I.N.; Korotkova, O.; Sinitsyn, A.P.; Schwaneberg, U.; Davari, M.D. Engineering Robust Cellulases for Tailored Lignocellulosic Degradation Cocktails. Int. J. Mol. Sci. 2020, 21, 1589. [CrossRef]

11. Skomarovsky, A.; Gusakov, A.; Okunev, O.; Solov'eva, I.; Bubnova, T.; Kondrat'eva, E.; Sinitsyn, A. Studies of hydrolytic activity of enzyme preparations of Penicillium and Trychoderma fungi. Appl. Biochem. Microbiol. 2005, 41, 182-184. [CrossRef]

12. Chekushina, A.; Dotsenko, G.; Sinitsyn, A. Comparing the efficiency of plant material bioconversion processes using biocatalysts based on Trichoderma and Penicillium verruculosum enzyme preparations. Catal. Ind. 2013, 5, 98-104. [CrossRef]

13. Proskurina, O.; Korotkova, O.; Rozhkova, A.; Matys, V.Y.; Koshelev, A.; Okunev, O.; Nemashkalov, V.; Sinitsyna, O.; Sinitsyn, A. Application of the "fusion" approach for the production of highly efficient biocatalysts based on recombinant strains of the fungus Penicillium verruculosum for the conversion of cellulose-containing biomass. Catal. Ind. 2013, 5, 327-334. [CrossRef]

14. Berlin, A.; Balakshin, M.; Gilkes, N.; Kadla, J.; Maximenko, V.; Kubo, S.; Saddler, J. Inhibition of cellulase, xylanase and $\beta$-glucosidase activities by softwood lignin preparations. J. Biotechnol. 2006, 125, 198-209. [CrossRef] [PubMed]

15. Morozova, V.; Semenova, M.; Rozhkova, A.; Kondrat'eva, E.; Okunev, O.; Bekkarevich, A.; Novozhilov, E.; Sinitsyn, A. Influence of the cycle number in processing of cellulose from waste paper on its ability to hydrolysis by cellulases. Appl. Biochem. Microbiol. 2010, 46, 363-366. [CrossRef]

16. Novozhilov, E.V.; Aksenov, A.S.; Demidov, M.L.; Chukhchin, D.G.; Dotsenko, G.S.; Osipov, D.O.; Sinitsyn, A.P. Application of complex biocatalysts based on recombinant Penicillium verruculosum enzyme preparations in the hydrolysis of semichemical hardwood pulp. Catal. Ind. 2014, 6, 348-354. [CrossRef] 
17. Novozhilov, E.; Sinel'nikov, I.; Aksenov, A.; Chukhchin, D.; Tyshkunova, I.; Rozhkova, A.; Osipov, D.; Zorov, I.; Sinitsyn, A. Biocatalytic conversion of kraft pulp using cellulase complex of Penicillium verruculosum. Catal. Ind. 2016, 8, 95-100. [CrossRef]

18. Tenkanen, M.; Tamminen, T.; Hortling, B. Investigation of lignin-carbohydrate complexes in kraft pulps by selective enzymatic treatments. Appl. Microbiol. Biotechnol. 1999, 51, 241-248. [CrossRef]

19. Ramos, L.; Nazhad, M.; Saddler, J. Effect of enzymatic hydrolysis on the morphology and fine structure of pretreated cellulosic residues. Enzym. Microb. Technol. 1993, 15, 821-831. [CrossRef]

20. Zhang, X.; Qin, W.; Paice, M.G.; Saddler, J.N. High consistency enzymatic hydrolysis of hardwood substrates. Bioresour. Technol. 2009, 100, 5890-5897. [CrossRef]

21. Wu, S.; Chang, H.; Phillips, R.; Jameel, H. Techno-economic analysis of the optimum softwood lignin content for the production of bioethanol in a repurposed kraft mill. BioResources 2014, 9, 6817-6830. [CrossRef]

22. Aldaeus, F.; Larsson, K.; Srndovic, J.S.; Kubat, M.; Karlström, K.; Peciulyte, A.; Olsson, L.; Larsson, P.T. The supramolecular structure of cellulose-rich wood pulps can be a determinative factor for enzymatic hydrolysability. Cellulose 2015, 22, 3991-4002. [CrossRef]

23. Buzała, K.; Przybysz, P.; Rosicka-Kaczmarek, J.; Kalinowska, H. Production of glucose-rich enzymatic hydrolysates from cellulosic pulps. Cellulose 2015, 22, 663-674. [CrossRef]

24. Buzała, K.; Przybysz, P.; Rosicka-Kaczmarek, J.; Kalinowska, H. Comparison of digestibility of wood pulps produced by the sulfate and TMP methods and woodchips of various botanical origins and sizes. Cellulose 2015, 22, 2737-2747. [CrossRef]

25. Buzała, K.P.; Przybysz, P.; Kalinowska, H.; Przybysz, K.; Kucner, M.; Dubowik, M. Evaluation of pine kraft cellulosic pulps and fines from papermaking as potential feedstocks for biofuel production. Cellulose 2016, 23, 649-659. [CrossRef]

26. Przybysz Buzała, K.; Kalinowska, H.; Małachowska, E.; Boruszewski, P.; Krajewski, K.; Przybysz, P. The Effect of Lignin Content in Birch and Beech Kraft Cellulosic Pulps on Simple Sugar Yields from the Enzymatic Hydrolysis of Cellulose. Energies 2019, 12, 2952. [CrossRef]

27. Branco, R.H.; Amândio, M.S.; Serafim, L.S.; Xavier, A.M. Ethanol Production from Hydrolyzed Kraft Pulp by Mono-and Co-Cultures of Yeasts: The Challenge of C6 and C5 Sugars Consumption. Energies 2020, 13, 744. [CrossRef]

28. Sjöberg, J.; Kleen, M.; Dahlman, O.; Agnemo, R. Analyses of carbohydrates and lignin in the surface and inner layers of softwood pulp fibers obtained employing various alkaline cooking processes. Nord. Pulp Pap. Res. J. 2002, 17, 295-301. [CrossRef]

29. Lawoko, M.; Henriksson, G.; Gellerstedt, G. Structural Differences between the Lignin-Carbohydrate Complexes Present in Wood and in Chemical Pulps. Biomacromolecules 2005, 6, 3467-3473. [CrossRef]

30. Chukhchin, D.G.; Bolotova, K.; Sinelnikov, I.; Churilov, D.; Novozhilov, E. Exosomes in the phloem and xylem of woody plants. Planta 2020, 251, 12. [CrossRef]

31. Lawoko, M.; Berggren, R.; Berthold, F.; Henriksson, G.; Gellerstedt, G. Changes in the lignin-carbohydrate complex in softwood kraft pulp during kraft and oxygen delignification. Holzforschung 2004, 58, 603-610. [CrossRef]

32. Wistara, N.; Young, R.A. Properties and treatments of pulps from recycled paper. Part I. Physical and chemical properties of pulps. Cellulose 1999, 6, 291-324. [CrossRef]

33. Fernandes Diniz, J.M.B.; Gil, M.H.; Castro, J.A.A.M. Hornification-its origin and interpretation in wood pulps. Wood Sci. Technol. 2004, 37, 489-494. [CrossRef]

34. Oksanen, T.; Buchert, J.; Viikari, L. The role of hemicelluloses in the hornification of bleached kraft pulps. Holzforsch. Int. J. Biol. Chem. Phys. Technol. Wood 1997, 51, 355-360. [CrossRef]

35. Rebuzzi, F.; Evtuguin, D.V. Effect of Glucuronoxylan on the Hornification of Eucalyptus globulus Bleached Pulps. Macromol. Symp. 2005, 232, 121-128. [CrossRef]

36. Kontturi, E.; Vuorinen, T. Indirect evidence of supramolecular changes within cellulose microfibrils of chemical pulp fibers upon drying. Cellulose 2009, 16, 65-74. [CrossRef]

37. Salmén, L. Wood morphology and properties from molecular perspectives. Ann. For. Sci. 2015, 72, 679-684. [CrossRef]

38. Xiao, Z.; Zhang, X.; Gregg, D.J.; Saddler, J.N. Effects of sugar inhibition on cellulases and $\beta$-glucosidase during enzymatic hydrolysis of softwood substrates. Appl. Biochem. Biotechnol. 2004, 115, 1115-1126. [CrossRef] 
39. Kumar, R.; Wyman, C.E. Strong cellulase inhibition by Mannan polysaccharides in cellulose conversion to sugars. Biotechnol. Bioeng. 2014, 111, 1341-1353. [CrossRef]

40. Laine, J.; Lindström, T.; Bremberg, C.; Glad-Nordmark, G. Studies on topochemical modification of cellulosic fibres. Part 4. Toposelectivity of carboxymethylation and its effects on the swelling of fibres. Nord. Pulp Pap. Res. J. 2003, 18, 316-324. [CrossRef]

41. Sinitsyn, A.; Gusakov, A.; Vlasenko, E.Y. Effect of structural and physico-chemical features of cellulosic substrates on the efficiency of enzymatic hydrolysis. Appl. Biochem. Biotechnol. 1991, 30, 43-59. [CrossRef]

42. Liu, Y.-S.; Baker, J.O.; Zeng, Y.; Himmel, M.E.; Haas, T.; Ding, S.-Y. Cellobiohydrolase hydrolyzes crystalline cellulose on hydrophobic faces. J. Biol. Chem. 2011, 286, 11195-11201. [CrossRef]

43. Agarwal, U.P.; Zhu, J.; Ralph, S.A. Enzymatic hydrolysis of loblolly pine: Effects of cellulose crystallinity and delignification. Holzforschung 2013, 67, 371-377. [CrossRef]

44. Fengel, D.; Wegener, G. Wood: Chemistry, Ultrastructure, Reactions; Walter de Gruyter: Berlin, Germany, 1984.

45. Gharehkhani, S.; Sadeghinezhad, E.; Kazi, S.N.; Yarmand, H.; Badarudin, A.; Safaei, M.R.; Zubir, M.N.M. Basic effects of pulp refining on fiber properties-A review. Carbohydr. Polym. 2015, 115, 785-803. [CrossRef] [PubMed]

46. Chauve, M.; Barre, L.; Tapin-Lingua, S.; da Silva Perez, D.; Decottignies, D.; Perez, S.; Ferreira, N.L. Evolution and impact of cellulose architecture during enzymatic hydrolysis by fungal cellulases. Adv. Biosci. Biotechnol. 2013, 4, 1095-1109. [CrossRef]

47. Ander, P.; Hildén, L.; Daniel, G. Cleavage of softwood kraft pulp by $\mathrm{HCl}$ and cellulases. BioResources 2008, 3, 477-490.

48. Clarke, K.; Li, X.; Li, K. The mechanism of fiber cutting during enzymatic hydrolysis of wood biomass. Biomass Bioenergy 2011, 35, 3943-3950. [CrossRef]

49. Thygesen, L.G.; Hidayat, B.J.; Johansen, K.S.; Felby, C. Role of supramolecular cellulose structures in enzymatic hydrolysis of plant cell walls. J. Ind. Microbiol. Biotechnol. 2011, 38, 975-983. [CrossRef]

50. Hidayat, B.J.; Felby, C.; Johansen, K.S.; Thygesen, L.G. Cellulose is not just cellulose: A review of dislocations as reactive sites in the enzymatic hydrolysis of cellulose microfibrils. Cellulose 2012, 19, 1481-1493. [CrossRef]

51. Evert, R.F. Esau's Plant Anatomy: Meristems, Cells, and Tissues of the Plant Body: Their Structure, Function, and Development; John Wiley \& Sons: Hoboken, NJ, USA, 2006.

52. Fergus, B.; Goring, D. The distribution of lignin in birch wood as determined by ultraviolet microscopy. Holzforsch. -Int. J. Biol. Chem. Phys. Technol. Wood 1970, 24, 118-124. [CrossRef]

53. Hayashi, T.; Maclachlan, G. Pea xyloglucan and cellulose: I. Macromolecular organization. Plant Physiol. 1984, 75, 596-604. [CrossRef]

54. Mansfield, S.D.; de Jong, E.; Stephens, R.S.; Saddler, J.N. Physical characterization of enzymatically modified kraft pulp fibers. J. Biotechnol. 1997, 57, 205-216. [CrossRef]

55. Wang, L.; Zhang, Y.; Gao, P.; Shi, D.; Liu, H.; Gao, H. Changes in the structural properties and rate of hydrolysis of cotton fibers during extended enzymatic hydrolysis. Biotechnol. Bioeng. 2006, 93, 443-456. [CrossRef] [PubMed]

56. Arantes, V.; Gourlay, K.; Saddler, J.N. The enzymatic hydrolysis of pretreated pulp fibers predominantly involves "peeling/erosion" modes of action. Biotechnol. Biofuels 2014, 7, 87-97. [CrossRef] [PubMed]

57. Novozhilov, E.; Tyshkunova, I.; Guryanova, A.; Terentyev, K.; Aksenov, A. COMPLEX USAGE OF THE SUBSTRATE IN THE BLEACHED KRAFT PULP ENZYMATIC HYDROLYSIS. Int. Multidiscip. Sci. Geoconference Sgem 2019, 19, 643-650.

58. Chukhchin, D.; Malkov, A.; Tyshkunova, I.; Mayer, L.; Novozhilov, E. Diffractometric method for determining the degree of crystallinity of materials. Crystallogr. Rep. 2016, 61, 371-375. [CrossRef]

59. Cosgrove, D.J. Growth of the plant cell wall. Nat. Rev. Mol. Cell Biol. 2005, 6, 850. [CrossRef] [PubMed]

60. Chebli, Y.; Geitmann, A. Cellular growth in plants requires regulation of cell wall biochemistry. Curr. Opin. Cell Biol. 2017, 44, 28-35. [CrossRef]

61. Zhao, Y.; Wu, B.; Yan, B.; Gao, P. Mechanism of cellobiose inhibition in cellulose hydrolysis by cellobiohydrolase. Sci. China Ser. C Life Sci. 2004, 47, 18-24. [CrossRef]

62. Dahlman, O.; Jacobs, A.; Sjöberg, J. Molecular properties of hemicelluloses located in the surface and inner layers of hardwood and softwood pulps. Cellulose 2003, 10, 325-334. [CrossRef]

63. Vena, P.; García-Aparicio, M.; Brienzo, M.; Görgens, J.; Rypstra, T. Effect of alkaline hemicellulose extraction on kraft pulp fibers from Eucalyptus grandis. J. Wood Chem. Technol. 2013, 33, 157-173. [CrossRef] 
64. Kont, R.; Kurašin, M.; Teugjas, H.; Väljamäe, P. Strong cellulase inhibitors from the hydrothermal pretreatment of wheat straw. Biotechnol. Biofuels 2013, 6, 135. [CrossRef]

65. Kim, Y.; Ximenes, E.; Mosier, N.S.; Ladisch, M.R. Soluble inhibitors/deactivators of cellulase enzymes from lignocellulosic biomass. Enzym. Microb. Technol. 2011, 48, 408-415. [CrossRef] [PubMed]

66. Qing, Q.; Yang, B.; Wyman, C.E. Xylooligomers are strong inhibitors of cellulose hydrolysis by enzymes. Bioresour. Technol. 2010, 101, 9624-9630. [CrossRef] [PubMed]

67. Zhang, J.; Tang, M.; Viikari, L. Xylans inhibit enzymatic hydrolysis of lignocellulosic materials by cellulases. Bioresour. Technol. 2012, 121, 8-12. [CrossRef] [PubMed]

68. Zhang, J.; Viikari, L. Xylo-oligosaccharides are competitive inhibitors of cellobiohydrolase I from Thermoascus aurantiacus. Bioresour. Technol. 2012, 117, 286-291. [CrossRef]

69. Ghose, T. Measurement of cellulase activities. Pure Appl. Chem. 1987, 59, 257-268. [CrossRef]

70. Bradford, M.M. A rapid and sensitive method for the quantitation of microgram quantities of protein utilizing the principle of protein-dye binding. Anal. Biochem. 1976, 72, 248-254. [CrossRef]

71. Karlsson, H. Fibre Guide: Fibre Analysis and Process Applications in the Pulp and Paper Industry: A Handbook; Lorentzen \& Wettre: Kista, Sweden, 2006.

72. Nelson, N. A photometric adaptation of the Somogyi method for the determination of glucose. J. Biol. Chem. 1944, 153, 375-380.

73. Kalliola, A.; Kuitunen, S.; Liitiä, T.; Rovio, S.; Ohra-aho, T.; Vuorinen, T.; Tamminen, T. Lignin oxidation mechanisms under oxygen delignification conditions. Part 1. Results from direct analyses. Holzforschung 2011, 65, 567-574. [CrossRef]

(C) 2020 by the authors. Licensee MDPI, Basel, Switzerland. This article is an open access article distributed under the terms and conditions of the Creative Commons Attribution (CC BY) license (http://creativecommons.org/licenses/by/4.0/). 